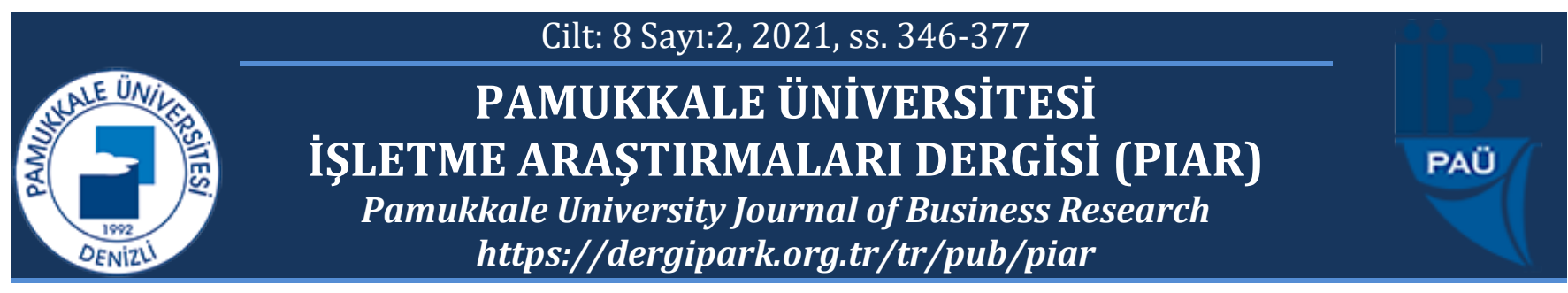

\title{
Denizli Esnaflarının Girişimcilik Özelliklerini İncelemeye Yönelik Bir Araştırma $^{1}$
}

\section{A Research to Examine The Entrepreneurial Characteristics of Tradesmen of Denizli}

\section{Ecem YILMAZ ${ }^{*}$}

2 yilmazzecem@hotmail.com, https://orcid.org/0000-0003-4520-8342

3Pamukkale Üniversitesi, İ̈BF, airmis@pau.edu.tr, https://orcid.org/0000-0002-9088-4529

*Yazışılan Yazar/Corresponding author
Makale Geliş/Received: 24.06.2021

\section{Öz}

Esnaflar ülke ekonomisinde rol oynayan ana unsurlardan biridir. Esnaflarm girişimcilik süreci toplumun ihtiyaçlarımın karşılanması, istihdamın sağlanması, daha büyük işletmelerin müşteriye ulaşmasinda köprü görevi görmesi, sermayenin daha geniş bir coğrafyaya yayılması vb. işlevleriyle ülke ekonomilerinin temel dinamiğini oluşturur. Buradan hareketle çalışmanın amacl, ülke ekonomisinin önemli bir parçası olan esnafların girişimcilik özelliklerinin neler olduğunu ortaya koymak ve bu özellikleri analiz etmektir. Denizli ticaretinin önemli bir merkezi olan Bayramyeri'nde faaliyet gösteren 250 esnaf ile anket yapılmıştır. Çalışmada örneklemi oluşturan esnafların girişimcilik özelliklerinin, sosyo-demografik özelliklere (yaş, eğitim düzeyi, faaliyette bulunulan sektör) göre anlamlı bir farklılık gösterip göstermediği elde edilen bulgular ile analiz edilmiştir. Araştırmanın örneklemini oluşturan esnaflarm girişimcilik düzeyleri orta seviyededir. Çalışmada başarı ihtiyacı, risk alma eğilimi, belirsizliğe tolerans, yenilik ve geleneksel zanaat bilgisi esnafların özelliği olarak ortaya çıkmıştır. Yapılan istatistiki analizler sonucunda esnafların başarı ihtiyacı yüksek, risk alma eğilimleri orta, belirsizliğe tolerans düzeyleri düşük, geleneksel zanaat bilgisi orta ve yenilik düzeyleri yüksek seviyededir. Çalışmanin sonunda araştırma sonuçları yorumlanarak, önerilerde bulunulmuştur.

Anahtar kelimeler: Girişimci, Girişimcilik Özellikleri, Esnaf, Esnaf Girişimci

JEL kodlart: M10, L26
Makale Kabul/Accepted: 22.09.2021

\section{Abstract}

Tradesmen is one of the main factors that play a role in the economy of the country. The entrepreneurship process of tradesmen is to meet the needs of the society, to provide employment, to act as a bridge for larger enterprises to reach customers, to spread the capital to a wider geography. It constitutes the basic dynamics of the country's economies with its functions. Based on this, the aim of the study is to reveal and analyze the entrepreneurial characteristics of the tradesmen, who are an important part of the country's economy. A survey was conducted with 250 tradesmen operating in Bayramyeri, an important center of Denizli trade. In the study, whether the entrepreneurship characteristics of the tradesmen constituting the sample differ significantly according to their socio-demographic characteristics (age, education level, the sector of activity) was analyzed with the obtained findings. The entrepreneurship levels of the tradesmen who make up the sample of the research are medium level. In the study, the need for success, risk taking tendency, tolerance to uncertainty, innovation and traditional craft knowledge emerged as the characteristics of tradesmen. As a result of the statistical analysis, the need for success of the tradesmen is high, their risk-taking tendency is medium, their tolerance to uncertainty is low, their traditional craft knowledge is medium and their level of innovation is high. At the end of the study, the research results were interpreted and suggestions were made.

Keywords: Entrepreneur, Entrepreneurship Characteristics, Tradesman, Tradesman Entrepreneur

JEL codes: M10, L26

\footnotetext{
1 Bu çalışma Ecem YILMAZ'ın “Denizli Esnaflarının Girişimcilik Özelliklerini İncelemeye Yönelik Bir Araştırma” başlıklı Yüksek Lisans Tezi'nden türetilmiştir.
} 


\section{GİRIŞ̧}

Girişimcilik, sanayi toplumundan bilgi toplumuna geçiş, teknolojik ve küresel gelişmeler gibi çok sayıda faktörün etkisiyle giderek artan ve yükselen ivme kazanmaktadır. 1980'lerden sonra gelişmiş ülkelerde küçük işletmelerin sayıca toplam işletmeler içindeki payı artarken büyük işletmelerin payının azalması ve işsizlik sorununun makro iktisadî politikalarla aşılamaması, küçük ve yeni işletmelere yönelik ilginin artmasına böylece küçük işletmeler için girişimcilik olgusunun daha fazla ön plana çıkmasına neden olmuştur (Işık vd., 2011: 149). Girişimcilikte önemli olan kimsenin göremediği, aklına getirmediği bir düşünceye sahip olmak ve bu fikri iş fırsatı olarak değerlendirebilmektir. Holding sahipliği, perakendecilik, kasaplık, tesisatçılık vb. geniş bir yelpaze içerisinde bir iş fikrine sahip olan, bu iş fikrini gerçeğe dönüştürebilme yetisi bulunan ve risk alabilen bireyler girişimci olarak kabul edilmektedir (Durukan, 2007: 29).

Girişimsel faaliyetlerin desteklenmesi ve geliştirilmesi ülkeler için bir zorunluluk haline gelmiştir. Ancak, ekonomik ve toplumsal hayatın temel kademe girişimcisi olan esnafların girişimcilik sürecindeki etkinliği ve işlevselliği girişimcilik literatüründe yeterince yer bulmamıştır. Hâlbuki esnafların yöre halkını üretime teşvik etmek, kişilerin gelir seviyelerini artırmak ve faaliyette bulunduğu bölgede yerel kalkınmaya öncülük etmek gibi birçok girişimsel fonksiyonu bulunmaktadır. Aynı zamanda esnafların üretim ve ticaret döngüsünde önemli bir köprü oldukları görülmektedir. Tüketiciye hizmet veren ve zanaatkâr olan esnaflar, üretim işletmelerinin kitle halinde üretilmiş ürünlerinin nihai müşteriye ulaştırılmasında ve hatta başka işletmelere bazı ara mamullerin temininde de önemli rol oynamaktadırlar. Esnafların girişimsel faaliyetleriyle ekonomik ve sosyal kalkınma için bu denli önemli rol oynuyor olması sebebiyle bu çalışmanın amacı, esnafların girişimci kişilik özelliklerini belirlemek ve analiz etmektir. Bu amaç doğrultusunda çalışmanın ilk bölümünde girişimci ve girişimcilik tanımlarına ve girişimciliğin önemine yer verilmiş ve girişimcinin özelliklerine değinilmiştir. Yapılan alan araştırmasında girişimcilik özelliklerinin belirlenebilmesi için Denizli'deki esnaflara anket çalışması yapılmış, elde edilen veriler istatistikî olarak analiz edilmiştir.

\section{GIRISSIMCILIK}

\subsection{Girişimci-Girişimcilik Kavramı ve Önemi}

Girişimci risk alma, öngörebilme, fırsatları değerlendirme, yaratıcı ve farklı düşüncelerle yenilik yapma ve yeni değerler yaratma sürecinin aktörüdür (Eroğlu vd., 2015: 536). Say'a göre girişimci; kaynakları yüksek verimlilik alanına doğru kaydırarak ekonomik alanda değer yaratır (Dees, 2001: 1). Girişimci, üretim faktörlerini birleştiren, bunları koordine ederek üretimin gerçekleşmesini sağlayan, ürünleri pazara ulaştıran ağı kuran ve bu süreçte yöneticilik ve liderlik rollerini üstelenen bir ekonomi ajanıdır (Bayrak ve Mert, 2016: 161). Bu bağlamıyla girişimciler değişen çevre koşulları ve yaşam tarzında yaşanan gelişme ve değişmelerle inisiyatif alan, kaynakları etkin kullanabilme kapasitesine bağlı olarak ekonomik ve sosyal çevrede yeni değerler üreten ve problemleri çözme yeteneği ile riski göze alabilen kişilerdir (Özdevecioğlu ve Karaca, 2015: 19).

Tarihsel sürece bakıldığında gelişen ve değişen dünya ekonomisi, ekonomik alandaki çok yönlü bakış açısı, rekabet koşulları ve tüm dünyayı etkisi altına alan kapitalizm gerçeği ile birlikte girişimcilik kavramı; bir tanım ve bir süreç olarak görülmenin ötesine geçmiştir 
(İrmiş ve Barutçu, 2012: 2). Özellikle sanayi devriminden itibaren giderek önemi artan girişimcilik kavramı; beraberinde getirdiği birçok olumlu faktör ile toplumların üzerinde etkisini büyük ölçüde hissettirmiştir. Girişimcilik ile yeni iş alanları topluma kazandırılmış, yeni istihdam alanları yaratılarak işsizlik azaltılmış, ekonomik ve teknolojik çevreye önemli katkılar yapılmıştır (Aksel ve Bağcl, 2016). Girişimcilik en dar tanımıyla yaratıcı insan faaliyetidir ve bir örgütü kurarak, onu faaliyete geçirme sürecinde rol alan temel öğedir (İrmiş ve Özdemir, 2011: 139). Girişimcilik sürecine dâhil olan fonksiyonlar; fırsatların keşfedilmesi, değerlendirilmesi ve kullanılmasıyla ilgilidir. Yeni ürünler, yeni hizmetler veya yeni üretim süreçleri hatta daha önce olmayan ürün ve girdiler için yeni stratejilerin oluşturulmasında yeni örgütlerin yapılandırılması ve yeni pazarların bulunması girişimcilik anlayışının en önemli fonksiyonlarıdır (Alvora vd., 2007: 2).

\subsection{Girişimcinin Özellikleri}

Koh girişimcileri tanımlayan bir takım kişilik özellikleri olduğunu ileri sürmüştür. Bu kişilik özellikleri girişimcilerin iş kurma ve risk alma isteklerini açıklamaya odaklanmıştır. Koh yaptığı çalışmada girişimcilik eğilimleri ile ilişkilendirilen bu özellikleri altı başlıkta incelemiş̧tir. Bunlar; başarma ihtiyacı, risk alma eğilimi, belirsizliğe tolerans, kendine güven, kontrol odağ1 ve yeniliktir (Koh, 1996: 14-17).

Başarma İhtiyacı: Girişimciler yeteneklerini zorlayan işlerin üstesinden gelmeye yönelik yüksek başarı ihtiyacı hissederek, durumu değerlendirir ve kendi becerileriyle kazanma şansını gördükleri işleri başarmak üzere sorumluluk alırlar (Aguinis vd., 2008: 123). McClelland yüksek düzeyde başarı ihtiyacı duyan toplumlarda daha fazla girişimcinin ortaya çıktığını kabul etmektedir (Apospori vd., 2005: 142).

Risk Alma Eğilimi: Risk alma, girişimcinin en önemli niteliklerinden biridir. Çünkü girişimcilik faaliyetleri belirsiz iş ortamlarında yürütülmekte ve risk bu faaliyetlerin merkez konumunda yer almaktadır. Uygun düzeyde kontrol edilen ve yönetilen risk başarılı girişimciliğin temel gerekliliğidir (Agbenyegah, 2013: 61).

Belirsizliğe Tolerans: Hofstede belirsizlikten kaçınma davranışını bir kültürün parçası olan bireylerin bilinmeyen ve kesin olmayan koşullarda kendini tehdit altında hissetmesiyle ilişkilendirir. Belirsizlikten kaçınmanın düşük olduğu toplumlarda bireylerin belirsizlikle mücadele etmeleri beklenir (Mueller ve Thomas, 2001: 60). Bireyler yüksek bilgi donanımı etkisinde nitelikli davranışlar sergiler ve diğer insanların içsel özelliklerine daha duyarlılık gösterirler. Bununla birlikte belirsizliğe toleransı yüksek kişiler eylemlerinde de girişimci özellikler göstermektedir (Sargut, 2001: 180).

Kendine Güven: Girişimcinin kendine güveni önceden belirlenmiş amaçlara ulaşmasında bir işi organize etmek ve yürütmek için iş yaratma sürecinde gerekli olan kişisel inancını ifade eder. Robinson ve arkadaşlarına göre (1991); girişimciler girişimci olmayan bireylere göre ayırt edici nitelikte bir özgüvene sahiptir (Nasip vd., 2017: 828).

Kontrol Odağı: Kontrol odağı ilk olarak Julian B. Rotter (1954 yılında) tarafından ifade edilmiş, daha sonra da içsel kontrol odaklılık ve dişsal kontrol odaklılık olarak kavramsallaştırılmıştır. İçsel kontrol odaklılıkta insanlar yaşamlarını kendilerinin kontrol edebildiklerine inanmaktadırlar. Dışsal kontrol odaklılıkta ise kendilerini etkileyen çevresel faktörlerin veya şans ve kader gibi faktörlerin kararlarını ve hayatlarını kontrol ettiğine 
inanırlar. Girişimci firmaları yöneten kişilerin yüksek iç kontrol odağına sahip oldukları düşünülmektedir. Ayrıca Gatawoot ve arkadaşlarının 1995 yılında yapmış olduğu çalışmada da girişimsel faaliyetlerin başarı faktörünün içsel kontrol odaklılıkla bağlantılı olduğu vurgulanmıştır (Nasip ve vd., 2017: 828).

Yenilik: Schumpeter yenilik yapmayı, girişimciliğin en temel ve belirgin unsuru olarak görmektedir (Dinis vd., 2013: 767). Yenilik ticari faaliyetlerin yeni ve benzersiz bakış açılarıyla algılanmasını ve gerçekleştirilmesini ifade etmektedir. Bu bağlamda yenilik, hâlihazırda bilinen bir ürüne yenilik katılarak piyasaya sunulması, bir ürünün henüz ilgili endüstride olmayan yeni bir üretim veya satış yöntemiyle pazara çıkarılması, yeni hammadde veya yarı mamul tedarik kaynaklarının temin edilmesi ve yeni endüstri sanayi yapılarının oluşturulması şeklinde de gerçekleşmektedir (Karol, 2013: 90).

\section{BİR GİRIșiMCi TIPOLOJísi OLARAK ESNAF GİRIŞ̦iMCí}

Bireyin girişimci olmasının ardında yatan ve girişimci olmasına sebep olan ana faktörler, ekonomik etkenler, eğitim, iş tecrübesi, inanç, rol modeller, aile, kültür ve bireyin karakteristik nitelikleridir. Söz konusu faktörler girişimci tipolojilerini meydana getirmektedir (Ball1, 2017: 151).

Esnaf hizmet veya ticaret alanında emek harcayan, tacir kadar kazanç sağlamayan (Salt, 2019: 26,33) sınırlı sermaye ile fiziki gücünü kullanarak faaliyetlerini gerçekleştiren kişilerdir. Esnafların, kısıtlı da olsa bir sermaye ve ağırlıklı beden gücü kullanarak iş kurma girişimini gerçekleştirmiş olması ve risk alması onların 'girişimci' özelliğe sahip olduğunu gösterir. Bu bağlamda, esnaflar, serbest piyasa ekonomisinin önemli bir halkasını oluşturan ve sosyal dengenin oluşumuna katkı sağlayan bağımsız-özgür girişimcilerdir (Çoban ve İrmiş, 2015: 30). Esnafların bir girişimci olarak düşünülmesinin yanı sıra, esnaf olmayan pek çok girişimcinin de esnaf özellikleri gösterdiğine dair literatürde özellikle 1960'lı yıllardan sonra birtakım çalışmalara rastlanılmaktadır. Smith (1967) girişimcileri kişisel özelliklerine ve iş motivasyonlarına göre (Campo, 2010: 56), fırsatçı girişimci (opportunistic entrepreneurs) ve esnaf girişimci (craftsman entrepreneurs) olarak iki grupta incelemiştir. Fursatçı girişimciler daha yüksek eğitim ve öğretim düzeyine sahip, gelişmiş sosyal farkındalığı olan, sosyal çevre ile başa çıkma becerileri gösteren ve geleceğin bilincinde olan girişimcilerdir (Smith ve Miner, 1983: 326). Bu kişilerin söz konusu özellikleri ile firmalarının değişen ve gelişen çevreye uyum sağlama olasılığı doğru orantılıdır. Fırsatçı girişimci özelliklerinin, şirketin ilk aşamalarından itibaren büyümesine ve gelişimine olumlu yönde katkı yaptığ1 düşünülür (Mujahid vd., 2019: 2).

Esnaf girişimciler ise şu an ve geçmiş odaklı düşünce yapısına sahip, genellikle eğitim seviyeleri düşük olan bireylerdir. Bu girişimciler işçilik deneyimine sahiptir ancak yönetim becerileri yoktur ve esnek olmayan katı firmalar kurma eğilimindedir. Literatürde zanaat girişimcisi olarak da ifade edilen bu girişimciler, işletmenin kurulması için gerekli olan finansal desteği çoğunlukla akraba ve arkadaşlarından sağlar (Nişancı, 2015: 18). Bu açıdan söz konusu girişimsel faaliyetler, genellikle yerel ve bölgesel ürün pazarlarını kullanan, ürün çeşitliliği sınırlı ve üretim araçlarını bulunduğu bölgeden karşılayan bir yapılanmadır (Ballı, 2017: 116).

Ülke ekonomilerinin yerel ve bölgesel pazarlarla gelişiyor olması esnaf girişimciliğinin ve 
esnaf girişimcilerinin özelliklerinin bilimsel araştırmalarla incelenmesini gerekli ve önemli kılmaktadır. Özellikle sanayi bölgelerinin ekonomik gelişmesinde çok küçük fakat oldukça etkili olan esnaf girişimleri ve esnaf girişimciliğinin bilimsel araştırmalara konu olması yerel kalkınmaya da katkı sağlayacaktır.

\section{DENIZLİ ESNAFLARININ GİRIŞIMCILIIK ÖZELLIKKLERINII İNCELEMEYE YÖNELIKK BIIR ARAŞTIRMA}

Esnaf girişimcilerin özellikleri dikkate alınarak Denizli esnafları üzerine bir alan araştırması gerçekleştirilmiştir. Girişimcilerin sosyo-demografik özellikleri ile girişimcilik özellikleri arasında ilişki kurulması onların girişimcilik vasıflarının geliştirilmesi açısından önemlidir. Literatürde de bu konuda yapılan araştırmalar mevcuttur.

Kâhya ve İmamoğlu'nun Bayburt ve esnafları üzerine yaptıkları çalışmada (2013) katılımcıların girişimcilik özelliklerinin, demografik özelliklerine göre farklılaşıp farklılaşmadığı test edilmiştir. Yapılan çalışmada esnafların yaşları ile girişimcilik özellikleri ve eğitim düzeyleri ile girişimcilik özellikleri arasında anlamlı bir farklılığa rastlanmamıştır.

Uzun ve Dirlik'in (2007) yaptığı araştırmada ise KOBİ sahiplerinin eğitim durumlarının girişimcilik özellikleri üzerinde pozitif yönlü etkiye sahip olduğu görülmüştür. Ayrıca, KOBİ sahiplerinin girişimcilik özelliklerinin onların işletmelerinin faaliyet süresini etkilemediği ancak KOBİ sahiplerinin girişimcilik özelliklerinin işletmelerin çalışan sayısına ve öz sermayelerine göre büyüklüğünü etkilediği görülmektedir.

Malatyalı girişimciler üzerine yapılan benzer bir çalışmada girişimcilerin çalışmakta olduğu endüstriyel faaliyet kolu, sektörde çalışma süreleri ve işletme mülkiyetine sahipliği ile girişimci özellikleri arasında anlamlı bir ilişki olduğu sonucuna ulaşılmıştır (Kuvan, 2007:237,243).

\subsection{Araştırmanın Amacı, Araştırma Soruları ve Hipotezler}

Günümüzün değişen şartlarında, rekabet koşullarına hızla ayak uyduran esnaflar, ülkenin gelir dağılımı içerisinde orta sınıfı oluşturur ve denge unsuru olarak görülürler. Genellikle emek yoğun teknolojileri kullanırlar ve ülkemizde özellikle işsizliğin azaltılmasında önemli bir rol üstlenirler (Demirer vd., 2017: 154). Üstelik esnaf girişimler, büyük işletmelerin ürünlerinin doğrudan pazara çıkmasında ve nihai tüketiciye ulaşmasında önemli bir katalizördür. Bununla beraber esnafların girişimcilik vasıflarını incelemek üzere yapılan alan araştırmaları oldukça az sayıdadır (Kâhya ve İmamoğlu, 2013; Çoban ve İrmiş, 2015). Literatürde esnaf girişimciliği kavramı üzerine çalışma yapılmış olmakla (Fılley ve Aldag, 1978; Ballı, 2017) beraber, esnafların bir girişimci olarak doğrudan incelendikleri çalışmalara yeterince yer verilmemiştir. Literatürdeki bu eksiklik de dikkate alınarak çalışmanın amacı, ülke ekonomisinin önemli bir parçası olan esnafların girişimcilik özelliklerini ortaya koymak ve bu özellikleri analiz etmek olarak belirlenmiştir. Çalışmanın amacı doğrultusunda hazırlanan araştırma soruları şunlardır:

Araştırma Sorusu 1: Denizli esnaflarının girişimcilik özellikleri nelerdir?

Araştırma Sorusu 2: Denizli esnaflarının girişimcilik özellikleri onların sosyo-demografik özelliklerine göre farklılaşmakta mıdır? 
Araştırma Sorusu 3: Denizli esnaflarının girişimcilik özellikleri onların kurdukları işletmelerin özelliklerine göre farklılaşmakta mıdır?

Araştırmanın ikinci ve üçüncü sorusu test edilmek üzere aşağıdaki hipotezler oluşturulmuştur.

Hı: Esnaf girişimcilerin yaşlarına göre, girişimcilik özelliklerini (alt boyutlarını) algılamaları arasında anlamlı farklılıklar vardır.

$\mathbf{H}_{2}$ : Esnaf girişimcilerin eğitim düzeylerine göre, girişimcilik özelliklerini (alt boyutlarını) algılamaları arasında anlamlı farklılıklar vardır.

$\mathbf{H}_{3}$ : Esnaf girişimcilerin faaliyette bulundukları sektöre göre girişimcilik özelliklerini (alt boyutlarını) algılamaları arasında anlamlı farklılıklar vardır.

$\mathbf{H}_{4}$ : Esnaf girişimcilerin iş̧letmelerinin kuruluş yılına göre girişimcilik özelliklerini (alt boyutlarını) algılamaları arasında anlamlı farklılıklar vardır.

H5: Esnaf girişimcilerin işletmelerinin hâlihazırdaki mülkiyetine göre, girişimcilik özelliklerini (alt boyutlarını) algılamaları arasında anlamlı farklılıklar vardır.

H6: Esnaf girişimcilerin işletmelerindeki mamulün tedarik şekline göre, girişimcilik özelliklerini (alt boyutlarını) algılamaları arasında anlamlı farklılıklar vardır.

$\mathbf{H}_{7}$ : Esnaf girişimcilerin işletmelerinin kendi mülkiyetinde olduğu dönemdeki büyüme durumlarına göre, girişimcilik özelliklerini (alt boyutlarını) algılamaları arasında anlamlı farklılıklar vardır.

Hs: Esnaf girişimcilerin işletmelerini gelecekte büyütme durumlarına göre, girişimcilik özelliklerini (alt boyutlarını) algılamaları arasında anlamlı farklılıklar vardır.

H9: Esnaf girişimcilerin işletmelerindeki çalıșan sayısına göre, girişimcilik özelliklerini (alt boyutlarını) algılamaları arasında anlamlı farklılıklar vardır.

H10: Esnaf girişimcilerin işletmelerinin son bir yıl içerisinde pandemi nedeniyle küçülme durumlarına göre, girişimcilik özelliklerini (alt boyutlarını) algılamaları arasında anlamlı farklılıklar vardır.

\subsection{Araştırmanın Yöntemi ve Veri Toplama Araçları}

Araştırmada niceliksel veri toplama aracı olan anket tekniği kullanılmış olup, anketler katılımcılara yüz yüze anket ve elektronik posta aracılığıyla ulaştırılmıştır. Araştırma sorularına cevap aramak ve hipotezleri test etmek üzere hazırlanan ve kullanılan anket iki bölümden oluşmaktadır. İlk bölümde katılımcıların sosyo-demografik bilgilerine ve işletmelerinin özelliklerine yönelik sorular sorulmuştur. İkinci bölümde ise esnafların girişimci kişilik özelliklerini belirlemek için Selma Kırılmaz'ın (2012) 'Sosyal Girişimciliğin Başarı Faktörlerinin Girişimci Kişilik ve Dönüştürücü Liderlik Bağlamında Araştırılması' adlı çalışmasında kullandığı girişimcilerin kişilik özelliklerinin belirlenmesi için kullanılan ölçekten faydalanılmıştır. Kırılmaz'ın araştırmasında kullandığı ölçek hazırlanırken girişimcilik özelliklerine yönelik faydalanılan alt ölçekler şunlardır: Başarı İhtiyacı (Heckert vd. 1999), İçsel Kontrol Odağı (Mueller ve Thomas, 2000), Risk Alma Eğilimi (Cho ve Lee, 2006) ve Belirsizliklere Karşı Toleranslı Olma (Norton, 1975) ve Yenilikçilik Ölçeği (Mueller ve Thomas, 2000)'dir. Katılımcıların ölçekte yer alan ifadelere katılım düzeylerini ölçmek 
amacıyla 5’li likert ölçümü kullanılmıştır. Ölçekteki sıklık dereceleri: 1-Hiç katılmıyorum, 2Katılmıyorum 3-Kararsızım, 4- Katılıyorum, 5-Tamamen Katılıyorum olarak ifade edilmiştir.

Ölçekte yer alan 6, 7, 8 ve 9. sorulardan oluşan içsel kontrol odağı boyutu katılımcılar tarafından tam anlaşılamadığı için analize tabi tutulmamıştır. Ölçekteki 13, 14, 15, 16, 17, 18, 21, 23, 24 ve 25 numaralı sorular ise cevapları ters çevrilerek değerlendirilmiştir.

Toplanan veriler SPSS 20 istatiksel paket programına aktarılarak analizlerin yapılması için hazır hale getirilmiştir. Araştırmanın geçerliliği ve güvenilirliğini ölçmek üzere faktör analizi ve güvenilirlik analizi yapılmıştır. Çalışmada yer alan veriler arasındaki farklılıkları incelemek için Independent-Samples T Test ve One-Way ANOVA testi kullanılmıştır.

\subsection{Araştırmanın Evreni ve Örneklemi}

Araştırmanın evrenini Denizli Bayramyeri'nde faaliyet gösteren esnaflar oluşturmaktadır. Anketler (yüz yüze ve elektronik posta yoluyla) Bayramyeri'nde faaliyet gösteren 300 esnafa dağıtılmıştır. Ancak 258 anket geri alınabilmiştir. Yeterli sayıda soruya cevap verilmediği için 8 anket çalışmaya dâhil edilmeyerek 250 anket üzerinden istatistiki analizler yapılmıştır.

\subsection{Güvenilirlik ve Geçerlilik Analizleri}

Çalışmada kullanılan girişimcilik ölçeği 26 ifadeden oluşmaktadır. İçsel kontrol odağı boyutu katılımcılar tarafından tam anlaşılamadığı için analize dâhil edilmemiştir. Her bir boyut için güvenilirlik katsayıları incelenmiştir. Bu boyutların güvenilirliğini arttırmak için bazı maddeler ölçekten çıkarılmıştır. Buna göre; 'Menkul kıymetler borsası benim için çok risklidir', 'Çok da yaratıcı bir insan değilim' ve 'Aynı işi farklı yollardan deneyerek yapmaktan hoşlanırım' ifadeleri analiz dışı bırakılmıştır. Yeni güvenilirlik analizi sonuçlarına göre alfa değerleri yükselmiştir. Kırılmaz'ın yaptığı çalışmada ölçeğin alpha değeri 0,68 olarak çıkmıştır. Bu çalışmada ise 19 ifadeli girişimcilik ölçeği için Cronbach Alpha Değeri 0,651 olarak hesaplanmıştır.

Tablo 1'de görüldüğü üzere, ölçeklere ilişkin KMO değeri 0,715; Bartlett'in küresellik testinin anlamlılık düzeyi 0,000 olarak çıkmıştır. Bu doğrultuda yapılan incelemeler sonucu veri setinin faktör analizine uygun olduğu görülmüştür.

Tablo 1. Girişimcilik Ölçeğine İlişkin KMO ve Barlett's Test Sonuçları

\begin{tabular}{|c|c|c|}
\hline \multicolumn{2}{|c|}{ Kaiser-Meyer-Olkin Örneklem Yeterliliği } & $\mathbf{7 1 5}$ \\
\hline \multirow{3}{*}{ Bartlett'in Küresellik Testi } & Yaklaşık ki-kare değeri & 1297,71 \\
\cline { 2 - 3 } & Serbestlik derecesi & 171 \\
\cline { 2 - 3 } & Anlamlımlı̈ düzeyi &, 000 \\
\hline
\end{tabular}

Seçilen maddelerin faktör dağılımını belirlemek için madde yükü alt sınırı/kestirim noktası 0,40 alınmış, varimax dik döndürme tekniği uygulanmış ve 19 ifade analize tabi tutulmuştur. Yapılan faktör analizi sonucunda 19 maddelik ve 5 faktörlü bir yapı elde edilmiştir. Elde edilen sonuçlar Tablo 2'de gösterilmektedir. Araştırmada kullanılan girişimcilik ölçeği yapılan faktör analizi sonucunda başarı ihtiyacı, risk alma, belirsizliğe tolerans, yenilik ve geleneksel zanaat bilgisi olarak beş boyuta ayrılmıştır. Geleneksel zanaat bilgisi boyutu girişimcilik özelliklerinin test edildiği diğer araştırmalarda oluşmamıştır. Bu çalışmada söz konusu boyutun oluşma sebebi araştırmanın evreninin özelliğinden kaynaklanmaktadır. Araştırmanın evrenini oluşturan kitlenin esnaflar olması, onların verdikleri cevaplar 
neticesinde 'esnaf girişimciliğinin' bir özelliği olan geleneksel zanaat bilgisi boyutunun oluşmasını sağlamıştır. Keşfedici faktör analizi sonucunda çıkan beş faktörün toplam varyansı yeterli düzeyde $(\% 58,568)$ açıladığı sonucuna ulaşılmıştır.

Tablo 2. Girişimcilik Ölçeği Faktör Yükleri

\begin{tabular}{|c|c|}
\hline İfadeler & $\begin{array}{r}\text { Faktör } \\
\text { Yükü }\end{array}$ \\
\hline Başarı İhtiyacı & 0,765 \\
\hline \multirow{5}{*}{$\begin{array}{l}\text { Kendimi yapabileceğim her şeyi yapmak için zorlarım. } \\
\text { İşimde performansımı geliştirmek için çok çabalarım. } \\
\text { Çok çalışkan biriyim } \\
\text { Mümkün olan en iyi işi yapmak benim için önemlidir. } \\
\text { İşimde elimden gelenin en iyisini yapmaya çalışırım. }\end{array}$} & ,736 \\
\hline & ,736 \\
\hline & 723 \\
\hline & ,721 \\
\hline & ,664 \\
\hline Risk Alma & 0,707 \\
\hline \multirow{3}{*}{$\begin{array}{l}\text { Yüksek gelir elde edebilmek için tasarruflarımın bir kısmını riskli yatırımlarda } \\
\text { değerlendirebilirim. } \\
\text { Yatırımlardan önemli finansal kazançlar elde etmek için büyük riskler alırım. } \\
\text { Bir yatırımdan uzun vadede kâr elde edeceksem, kısa vadede para kaybetme } \\
\text { riskini göze alırım. }\end{array}$} & 848 \\
\hline & ,783 \\
\hline & ,688 \\
\hline Belirsizliğe Tolerans & 0,759 \\
\hline \multirow{5}{*}{$\begin{array}{l}\text { Karar alma sürecinde, problemle ilgili yeterli bilgi ve veri yoksa kendimi çok } \\
\text { rahatsız hissederim. } \\
\text { Önemli bir göreve başlamadan önce onun ne kadar süreceğini bilmem gerekir. } \\
\text { Bir problemin çözümü olduğunu düşünmezsem, o problem benim için ilgi çekici } \\
\text { değildir. } \\
\text { Çözüm için belirli ve net bir cevap yoksa o problem üzerinde çalışmak istemem. } \\
\text { Bir işi bitirmeden yeni bir işe başlamaktan hoşlanmam. }\end{array}$} & ,769 \\
\hline & ,763 \\
\hline & ,723 \\
\hline & ,638 \\
\hline & ,571 \\
\hline Yenilik & 0,657 \\
\hline \multirow{3}{*}{$\begin{array}{l}\text { İnsanları sık sık yeni fikirlerimle şaşırtırım. } \\
\text { İnsanlar sık sık yaratıcı faaliyetler için benden yardım isterler. } \\
\text { Yaratıcı fikirlere ihtiyaç duyulan işlerde çalışmayı tercih ederim. }\end{array}$} & 810 \\
\hline & 797 \\
\hline & 611 \\
\hline Geleneksel Zanaat Bilgisi & 0,679 \\
\hline \multirow{3}{*}{$\begin{array}{l}\text { Yaratıcılıktan ziyade beceri ve uygulamaya yönelik bir işi tercih ederim. } \\
\text { Yeni bir işi genelde bana öğretildiği şekilde yapmaya devam ederim. } \\
\text { Yeni bir fikir ortaya atmaktansa bir beceri üzerinde uzmanlaşmak beni daha } \\
\text { fazla tatmin eder. }\end{array}$} & ,782 \\
\hline & 761 \\
\hline & 669 \\
\hline Açılanan Toplam Varyans & 58,568 \\
\hline Cronbach Alpha & 0,651 \\
\hline
\end{tabular}

Tablo 2'de görüldüğü üzere boyutların güvenilirliğine ilişkin katsayılar; başarı ihtiyacı boyutu için 0,765 , risk alma boyutu için 0,707 , belirsizliğe tolerans boyutu için 0,759 , yenilik boyutu için 0,657 ve geleneksel zanaat bilgisi boyutu için $0,679^{\prime}$ dur. 


\subsection{Katılımcıların Sosyo-Demografik Özellikleri ve İşletmelerinin Özelliklerine İlişkin Bulgular}

Katılımcların sosyo-demografik özellikleri olarak araştırmanın kapsamı bağlamında yaş dağılımı ve eğitim düzeyi incelenmiştir. Elde edilen sonuçlar Tablo 3 'te gösterilmektedir.

Tablo 3. Katılımcıların Sosyo-Demografik Özellikleri

\begin{tabular}{|lcc|}
\hline & Frekans & Yüzde \\
\hline Yaş dağılımı & & \\
\hline $18-25$ & 25 & 10,0 \\
$26-30$ & 49 & 19,6 \\
$31-35$ & 47 & 18,8 \\
$36-40$ & 42 & 16,8 \\
$41-45$ & 30 & 12,0 \\
$46-50$ & 21 & 8,4 \\
$50+$ & 36 & 14,4 \\
\hline Ĕ̆itim düzeyi & \multicolumn{2}{|c|}{} \\
\hline İlköğretim & 41 & 16,4 \\
Lise & 103 & 41,2 \\
Ön lisans & 33 & 13,2 \\
Lisans ve lisansüstü & 73 & 29,2 \\
\hline
\end{tabular}

Yaş gruplarına göre dağılım incelendiğinde katılımcıların \%65,2'sinin 40 yaş ve altındaki katılımcılardan oluştuğu, \%12'sinin 41-45 yaşları arasında, \%8,4'ünün 46-50 yaşları arasında ve \%14,4'ünün 50 yaşın üzerinde olduğu görülmektedir. Eğitim düzeylerine göre ise katılımcıların yarısından fazlası $(\% 57,6)$ ilköğretim ve lise mezunu, \%13,2'si ön lisans, $\% 29,2$ 'si lisans ve lisansüstü mezunudur.

Katılımcıların işletmelerinin özellikleri olarak, işletmenin içinde yer alan sektör, kuruluş yılları, şu anki mülkiyeti, tedarik durumu, kendi mülkiyetindeyken işletmenin büyüme durumu, işletmelerini gelecekte büyütme ihtimali, işletmedeki çalışan sayısı ve işletmenin pandemi sürecindeki durumu incelenmiştir. Elde edilen sonuçlar Tablo 4'te gösterilmektedir. 
Tablo 4. Katılımcıların İşletmelerinin Özellikleri

\begin{tabular}{|c|c|c|}
\hline \multicolumn{3}{|l|}{ Katılımcıların faaliyette bulunduğu sektör } \\
\hline Tekstil & 84 & 33,6 \\
\hline Gida & 44 & 17,6 \\
\hline Otomotiv & 35 & 14,0 \\
\hline Ayakkabicilık & 12 & 4,8 \\
\hline Kuyumculuk & 20 & 8,0 \\
\hline Diğer & 55 & 22,0 \\
\hline \multicolumn{3}{|l|}{ Katılımcıların işletmelerinin kuruluş yılları } \\
\hline 1980 öncesi & 34 & 13,6 \\
\hline 1980-1989 & 27 & 10,8 \\
\hline 1990-1999 & 23 & 9,2 \\
\hline 2000-2009 & 46 & 18,4 \\
\hline 2010-2015 & 43 & 17,2 \\
\hline 2016 ve sonrasi & 65 & 26,0 \\
\hline \multicolumn{3}{|l|}{ Katılımcıların işletmelerinin mülkiyeti } \\
\hline Mülkiyeti tamamen bana aittir. & 131 & 52,4 \\
\hline Aile ortaklığıdır. & 80 & 32,0 \\
\hline Aileden olmayan kişilerle ortaklık vardır. & 39 & 15,6 \\
\hline \multicolumn{3}{|l|}{ Katılımcıların işletmelerinin tedarik durumu } \\
\hline $\begin{array}{l}\text { Satışını yaptığımız mamulün üretimini yapan kendi } \\
\text { işletmemiz var }\end{array}$ & 50 & 20,0 \\
\hline Başka işletmelerden satın alıyoruz & 200 & 80,0 \\
\hline \multicolumn{3}{|l|}{ Katılımcıların işletmelerini büyütme durumu } \\
\hline Evet & 207 & 82,8 \\
\hline Hayır & 43 & 17,2 \\
\hline \multicolumn{3}{|l|}{ Katılımcıların işletmelerini gelecekte büyütme ihtimali } \\
\hline Evet & 203 & 81,2 \\
\hline Hayır & 47 & 18,8 \\
\hline \multicolumn{3}{|l|}{ Katılımcıların işletmelerindeki çalışan sayısı } \\
\hline Çalışanım yok & 76 & 30,4 \\
\hline 1 kişi & 39 & 15,6 \\
\hline 2 kişi & 40 & 16,0 \\
\hline 3 kişi & 27 & 10,8 \\
\hline 4 kişi & 9 & 3,6 \\
\hline 5 kişi & 11 & 4,4 \\
\hline $5+$ & 48 & 19,2 \\
\hline \multicolumn{3}{|l|}{$\begin{array}{l}\text { Katılımcıların işletmelerinin pandemi sürecindeki küçülme } \\
\text { durumu }\end{array}$} \\
\hline Evet & 127 & 50,8 \\
\hline Hayır & 123 & 49,2 \\
\hline
\end{tabular}

Katılımcıların işletmelerinin özelliklerini gösteren Tablo $4^{\prime}$ e bakıldığında, katılımcıların faaliyette bulundukları sektörlerin; \%33,6'sının tekstil, \%17,6'sının gıda, \%14'ünün otomotiv, 
\%4,8'inin ayakkabıcılık ve \%8'inin kuyumculuk sektörü olduğu görülmektedir. Diğer seçeneğini işaretleyen katılımcılar, ağırlıklı olarak mobilya, bakırcılık, demircilik, çiçekçi, kırtasiye ve kuaför sektöründe faaliyet göstermektedir. Katılımcıların \%61,6'sı işletmelerini son yirmi yıl içerisinde kurarken, bunların içinden $\% 26^{\prime}$ sı da son beş yıl içerisinde işletmelerini kurmuştur. Katılımcıların \%52,4'ünde işletme mülkiyeti sadece kendilerine aittir. \%32'si aile ortaklığıla \%15,6'sı da aileden olmayan kişilerle yaptıkları ortaklıkla işletmelerini kurmuşlardır. Tablo 4 incelendiğinde, katılımcıların \%20'sinin satışını yaptıkları mamulün üretimini de yapan kendilerine ait işletmelerinin olduğu ve \%80'inin tedarikini başka işletmelerden yapıldığ 1 görülmektedir. Katılımcıların \%82,8'i işletmelerinin kendi mülkiyetlerinde olduğu sürede büyüme gösterdiğini ve $\% 81,2$ 'si de işletmelerini gelecekte büyütebileceklerini ifade etmişlerdir. Katılımcıların \%30,4'ünün hiç çalışanı bulunmamaktadır. Tablo 4'e göre katılımcıların yarısı (\%50,8'i) yaşanılan pandemi ve etkileri sebebiyle küçülmeye gitmiştir.

Katılımcıların bir işletmenin devamlılığın sağlanmasında etkili olduğunu düşündüğü durumların yüzdelik dilimleri, Tablo 5'de gösterilmektedir.

Tablo 5. Katılımcıların Bir İşletmenin Devamlılığın Sağlanmasında Etkili Olduğu Düşündüğü Durumların Yüzdelik Oranları

\begin{tabular}{|c|c|c|c|c|c|c|c|c|c|c|}
\hline \multirow[t]{2}{*}{$\begin{array}{l}\text { Yüzdelik } \\
\text { Dilim } \\
(\%)\end{array}$} & \multicolumn{2}{|c|}{$\begin{array}{l}\text { İşletme } \\
\text { Sahibinin } \\
\text { Ahlâkı }\end{array}$} & \multicolumn{2}{|c|}{$\begin{array}{l}\text { Piyasa } \\
\text { Ahlâkı }\end{array}$} & \multicolumn{2}{|c|}{$\begin{array}{c}\text { Devlet } \\
\text { Katkısı ve } \\
\text { Etkisi } \\
\end{array}$} & \multicolumn{2}{|c|}{$\begin{array}{c}\text { Değişikliklere } \\
\text { Ayak } \\
\text { Uydurmak }\end{array}$} & \multicolumn{2}{|c|}{$\begin{array}{c}\text { Yenilikçi } \\
\text { Olmak }\end{array}$} \\
\hline & Say1 & Yüzde & Say1 & Yüzde & Say1 & Yüzde & Sayı & Yüzde & Sayı & Yüzde \\
\hline$\% 0-\% 20$ & 99 & 43,8 & 177 & 78,3 & 195 & 86,3 & 183 & 81,0 & 170 & 75,2 \\
\hline$\% 21-\% 40$ & 85 & 37,6 & 43 & 19,0 & 26 & 11,5 & 39 & 17,3 & 52 & 23,0 \\
\hline$\% 41-\% 60$ & 26 & 11,5 & 6 & 2,7 & 4 & 1,8 & 4 & 1,8 & 2 & 9 \\
\hline$\% 61-\% 80$ & 13 & 5,8 & - & - & 1 & ,4 & - & - & 2 & 9 \\
\hline $\begin{array}{l}\% 81- \\
\% 100\end{array}$ & 3 & - & - & - & - & - & - & - & - & - \\
\hline TOPLAM & 226 & 100,0 & 226 & 100,0 & 226 & 100,0 & 226 & 100,0 & 226 & 100,0 \\
\hline
\end{tabular}

Katılımcıların işletmenin devamlılığını en fazla \%20 kadar etkileyebileceğini, başka bir ifadeyle en düşük düzeyde etkileyeceğini düşündükleri unsurlar sırasıyla devlet katkısı ve etkisi (\%86,3); değişikliklere ayak uydurmak (\%81,0), piyasa ahlâkı $(\% 78,3)$; yenilikçi olmak $(\% 75,2)$ ve en düşük katılımla işletme sahibinin ahlâkıdır $(\% 43,8)$. İşletmenin devamlılığına \%20-\%40 arasında etkisinin olduğu düşünülen unsurların girişimciler arasındaki dağılımı ise sırasıyla \%37,6 ile işletme sahibinin ahlâkı, \% 23 ile yenilikçi olma, \%19 ile piyasa ahlâkı, $\% 17,3$ ile değişikliklere ayak uydurma ve \%11,5 ile devlet katkısı ve etkisidir.

Tablo 5'e göre katılımcıların \%18,6'sı (42 kişi) işletme sahibinin ahlâkının işletmenin devamlılığına etkisinin diğer faktörlere göre \%40'dan daha fazla etkili olduğunu ifade etmiştir. Hatta \%7,1'i (16 kişi) işletme sahibinin ahlâkının \%60'dan daha fazla önemli olduğunu düşünmektedir. Bu durumda Tablo 5'e göre işletmenin devamlılığındaki etkisinin $\% 40$ 'dan daha fazla olduğunun düşünüldüğü, diğerlerine göre en yüksek oranlı unsur 'işletme sahibinin ahlâkı' olarak görülmektedir. Piyasa ahlâk1 \%2,7; devletin etkisi ve katkısı 
\%2,2; değişikliklere ayak uydurmak ile yenilikçi olmak da \%1,8'lik oranlarla işletmenin devamlılığını \%40'dan daha fazla etkileyen unsurlar olarak görülmektedir. Bu durumda esnafların, işletmenin devamlılığında en etkili olarak gördükleri unsur işletme sahibinin ahlâkıdır.

\subsection{Araştırmada Kullanılan Ölçeklere İlişkin Temel Göstergeler}

Araştırma kapsamında oluşturulan varsayımların değerlendirilebilmesi için girişimcilik özelliklerini ölçen ifadelerin ortalama ve standart sapmaları tanımlayıcı analiz yöntemiyle hesaplanmıştır. Varsayımların değerlendirilmesi yapılırken veriler ortalamanın aldıkları değerlere göre düşük, orta ve yüksek olmak üzere üç düzeyde incelenmişlerdir. Bu düzeyler şöyle ifade edilmektedir:

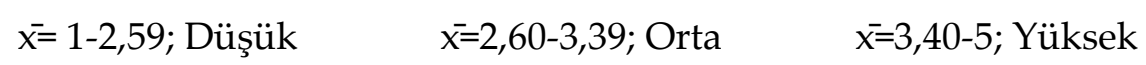

Tablo 6. Katılımciların Girişimcilik Düzeyleri

\begin{tabular}{|c|c|c|c|}
\hline Girişimcilik Özellikleri & Ortalama & Standart Sapma & Düzey \\
\hline Girişimcilik Düzeyi & $\mathbf{3 , 2 7 8 7 6 8}$ & $\mathbf{1 , 0 7 2 0 1}$ & Orta \\
\hline Başarı İhtiyacı & 4,2842 & 0,55145 & Yüksek \\
\hline Risk Alma & 2,8733 & 1,27645 & Orta \\
\hline Belirsizliğe Tolerans & 2,3272 & 1,282474 & Düşük \\
\hline Yenilik & 3,6728 & 1,15664 & Yüksek \\
\hline Geleneksel Zanaat Bilgisi & 2,6266 & 1,29978 & Orta \\
\hline
\end{tabular}

Araştırmada kullanılan girişimci kişilik özellikleri ölçeği yapılan faktör analizi sonucunda başarma ihtiyac1, risk alma, belirsizliğe tolerans, yenilik ve geleneksel zanaat bilgisi olarak beş boyuta ayrılmıştır. Geleneksel zanaat bilgisi boyutu girişimcilik özelliklerinin test edildiği diğer araştırmalarda oluşmamıştır. Bu çalışmada geleneksel zanaat bilgisi boyutunun oluşma sebebi araştırmanın evreninin özelliğinden kaynaklanmaktadır. Araştırmanın evrenini oluşturan kitlenin esnaflar olması, onların verdikleri cevaplar neticesinde 'esnaf girişimciliğinin' bir özelliği olan geleneksel zanaat bilgisi boyutunun oluşmasını sağlamıştır. Esnafların sosyo-demografik özelliklerine ve işletmelerinin özelliklerine göre girişimcilik özelliklerinin nasıl farklılaştı̆̆ını analiz etmek üzere istatistiki testler yapılmıştır. Yapılan normallik testi sonucunda girişimcilik özelliklerinin beş boyutu için elde edilen değerler $+1,5$ ile $-1,5$ aralığındadır. Bu durum verilerin normal dağıldığını ve hipotez testlerinde parametrik analiz yöntemlerinin kullanılabileceğini göstermektedir. İki grup arasında farklılıkların incelenmesi amacıyla T-testi, ikiden fazla grup farklılıklarının karşılaştırılması amacıyla ANOVA testi, gruplar arasında fark olduğunda ise farkın hangi gruplar arasında olduğunu bulabilmek için Tukey Post Hoc analizleri kullanılmıştır.

Araştırmada kullanılan testlerin sonuçları değerlendirildiğinde hesaplanan anlamlılık seviyesi olan significance (2-tailed) değerinin \%5 anlamlılık düzeyi için,

Eğer Sig. (2-tailed) değeri > 0,05 ise gruplar arasında anlamlı fark yoktur

Eğer Sig. (2-tailed) değeri $<0,05$ ise gruplar arasında anlamlı fark vardır yorumu yapılmaktadır (Coşkun vd., 2017: 202). 


\subsubsection{Sosyo-Demografik Değişkenler ve Girişimcilik Özelliği Boyutları}

Araştırmanın bu kısmında anket formunun ilk kısmında yer alan sosyo-demografik değişkenlerin ve işletmelerin özelliklerinin girişimci kişilik özelliği boyutlarına göre farklılaşıp farklılaşmadığına dair testler yer almaktadır. Girişimcilik alt boyutlarının yaşa ilişkin farklılıkları Tablo 7'de gösterilmektedir.

Tablo 7. Girişimcilik Alt Boyutlarının Yaşa İlişkin Farklılıkları

\begin{tabular}{|c|c|c|c|c|c|c|c|}
\hline Boyut & $\begin{array}{c}\text { Yaş } \\
\text { Grupları } \\
\end{array}$ & $\begin{array}{c}\text { Ortalama } \\
(\mathrm{x})\end{array}$ & $\begin{array}{c}\text { Standart } \\
\text { Sapma }\end{array}$ & $\mathbf{F}$ & $\begin{array}{c}\text { Levene } \\
\text { Testi Anl. }\end{array}$ & Sig (P) & Fark \\
\hline \multirow{7}{*}{ Başarı İhtiyacı } & $18-25$ & 4,6480 & ,45196 & \multirow{7}{*}{1,187} & \multirow{7}{*}{1,235} & \multirow{7}{*}{,314 } & \multirow{7}{*}{ - } \\
\hline & $26-30$ & 4,5286 & , 40305 & & & & \\
\hline & $31-35$ & 4,6638 & ,36381 & & & & \\
\hline & $36-40$ & 4,5714 & ,43409 & & & & \\
\hline & $41-45$ & 4,6400 & ,41490 & & & & \\
\hline & $46-50$ & 4,7524 & ,40941 & & & & \\
\hline & $50+$ & 4,6889 & 35599 & & & & \\
\hline \multirow{7}{*}{ Risk Alma } & $18-25$ & 3,1333 & ,89235 & \multirow{7}{*}{3,711} & \multirow{7}{*}{,717 } & \multirow{7}{*}{,002 } & \multirow{7}{*}{$\begin{array}{c}18-25 \\
26-30 \\
50+\end{array}$} \\
\hline & $26-30$ & 3,2041 & ,99726 & & & & \\
\hline & $31-35$ & 2,7872 & 1,04587 & & & & \\
\hline & $36-40$ & 2,8413 & ,89636 & & & & \\
\hline & $41-45$ & 2,9778 & 1,08254 & & & & \\
\hline & $46-50$ & 2,9524 & 1,02353 & & & & \\
\hline & $50+$ & 2,2593 & ,91586 & & & & \\
\hline \multirow{7}{*}{$\begin{array}{l}\text { Belirsizliğe } \\
\text { Tolerans }\end{array}$} & $18-25$ & 2,3440 & ,88979 & \multirow{7}{*}{1,747} & \multirow{7}{*}{,954 } & \multirow{7}{*}{ 111 } & \multirow{7}{*}{ - } \\
\hline & $26-30$ & 2,2980 & ,77365 & & & & \\
\hline & $31-35$ & 2,6213 & ,99846 & & & & \\
\hline & $36-40$ & 2,2000 & ,86785 & & & & \\
\hline & $41-45$ & 1,9800 & ,97323 & & & & \\
\hline & $46-50$ & 2,3238 & ,79114 & & & & \\
\hline & $50+$ & 2,4111 & 1,01974 & & & & \\
\hline \multirow{7}{*}{ Yenilik } & $18-25$ & 3,8000 & ,77579 & \multirow{7}{*}{3,319} & \multirow{7}{*}{,852 } & \multirow{7}{*}{,004 } & \multirow{7}{*}{$\begin{array}{c}26-30 \\
41-45 \\
46-50 \\
50+ \\
\end{array}$} \\
\hline & $26-30$ & 3,8274 & ,75575 & & & & \\
\hline & $31-35$ & 3,6525 & ,83971 & & & & \\
\hline & $36-40$ & 3,5238 & ,83987 & & & & \\
\hline & $41-45$ & 3,8556 & ,90416 & & & & \\
\hline & $46-50$ & 4,0635 & 86679 & & & & \\
\hline & $50+$ & 3,1944 & 1,07902 & & & & \\
\hline \multirow{7}{*}{$\begin{array}{c}\text { Geleneksel } \\
\text { Zanaat Bilgisi }\end{array}$} & $18-25$ & 2,4800 & 1,13480 & \multirow{7}{*}{2,105} & \multirow{7}{*}{1,250} & \multirow{7}{*}{053} & \multirow{7}{*}{-} \\
\hline & $26-30$ & 2,7347 & ,87923 & & & & \\
\hline & $31-35$ & 2,9220 & ,95100 & & & & \\
\hline & $36-40$ & 2,7381 & ,96423 & & & & \\
\hline & $41-45$ & 2,2222 & ,96424 & & & & \\
\hline & $46-50$ & 2,6508 & 1,31435 & & & & \\
\hline & $50+$ & 2,3889 & ,99682 & & & & \\
\hline
\end{tabular}

Varyans sonuçlarına göre ( $\mathrm{p}<0,05$ olduğu için) sadece risk alma ve yenilik boyutları yaşa göre farklılık göstermektedir. Post Hoc testi sonuçlarına bakıldığında risk alma boyutuna 
göre oluşan farklılık 50+ ile 18-25 ve 26-30 yaş aralığında olmaktadır. Buna göre ortalama değerlere bakıldığında esnafların yaşı artıkça risk alma eğilimleri düşmektedir. 26-30 yaş aralığında olan katılımcıların risk alma eğilimleri diğer yaş gruplarına kıyasla daha fazladır. Post Hoc testi sonuçlarına göre yenilik boyutuna göre bu farklılık, 26-30 yaş aralığında (3.83), 41-45 yaş aralığında (3.86), 46-50 yaş aralığında (4.06) ve 50 üstü yaş aralığında (3.19) görülmektedir. Buna göre ortalama değerlere bakıldığında yenilik boyutu en fazla 46-50 yaş aralığında, daha sonra da 41-45 yaş aralığında diğer yaş aralıklarına göre daha yüksek bir ortalamaya sahiptir. Bununla beraber yenilik boyutundaki en düşük oran 50 yaş üstünde görülmektedir. Analiz sonucunda $\mathrm{H}_{1}$ 'in risk alma ve yenilik boyutunda desteklendiği diğer boyutlarda desteklenmediği görülmektedir. Girişimcilik alt boyutlarının eğitim düzeyine ilişkin farklılıkları Tablo 8'de gösterilmektedir.

Tablo 8. Girişimcilik Alt Boyutlarının Eğitim Düzeyine İlişkin Farklılıkları

\begin{tabular}{|c|c|c|c|c|c|c|c|}
\hline Boyut & $\begin{array}{l}\text { Eğitim } \\
\text { Düzeyi }\end{array}$ & $\begin{array}{c}\text { Ortalama } \\
(\vec{x})\end{array}$ & $\begin{array}{l}\text { Standart } \\
\text { Sapma }\end{array}$ & $\mathbf{F}$ & $\begin{array}{c}\text { Levene } \\
\text { Testi } \\
\text { Anl. }\end{array}$ & $\begin{array}{l}\text { Sig } \\
(p)\end{array}$ & Fark \\
\hline \multirow{4}{*}{$\begin{array}{l}\text { Başarı } \\
\text { İhtiyacı }\end{array}$} & İlköğretim & 4,6049 & 39112 & \multirow{4}{*}{840} & \multirow{4}{*}{1,717} & \multirow{4}{*}{,473 } & \multirow{4}{*}{-} \\
\hline & Lise & 4,6593 & ,41356 & & & & \\
\hline & Ön lisans & 4,6788 & ,33143 & & & & \\
\hline & $\begin{array}{l}\text { Lisans ve } \\
\text { lisansüstü }\end{array}$ & 4,5753 & 42419 & & & & \\
\hline \multirow{4}{*}{ Risk Alma } & İlköğretim & 2,4634 & ,93357 & \multirow{4}{*}{5,732} & \multirow{4}{*}{2,182} & \multirow{4}{*}{,001 } & \multirow{4}{*}{$\begin{array}{l}\text { İlköğretim- } \\
\text { Lise- Ön } \\
\text { Lisans }\end{array}$} \\
\hline & Lise & 2,9773 & 1,07887 & & & & \\
\hline & Ön lisans & 3,3232 & ,94091 & & & & \\
\hline & $\begin{array}{l}\text { Lisans ve } \\
\text { lisansüstü }\end{array}$ & 2,7534 & 89929 & & & & \\
\hline \multirow{4}{*}{$\begin{array}{c}\text { Belirsizliğe } \\
\text { Tolerans }\end{array}$} & İlköğretim & 2,4634 & , 93855 & \multirow{4}{*}{3,702} & \multirow{4}{*}{ 682 } & \multirow{4}{*}{,012 } & \multirow{4}{*}{$\begin{array}{c}\text { Lise-Lisans } \\
\text { ve } \\
\text { Lisansüstü }\end{array}$} \\
\hline & Lise & 2,1553 & ,91606 & & & & \\
\hline & Ön lisans & 2,1576 & ,74290 & & & & \\
\hline & $\begin{array}{l}\text { Lisans ve } \\
\text { lisansüstü }\end{array}$ & 2,5699 & ,92776 & & & & \\
\hline \multirow{4}{*}{ Yenilik } & İlköğretim & 3,4604 & 89666 & \multirow{4}{*}{,959 } & \multirow{4}{*}{3,799} & \multirow{4}{*}{,413 } & \multirow{4}{*}{ - } \\
\hline & Lise & 3,6990 & ,99838 & & & & \\
\hline & Ön lisans & 3,7071 & 65488 & & & & \\
\hline & $\begin{array}{l}\text { Lisans ve } \\
\text { lisansüstü }\end{array}$ & 3,7397 & 81507 & & & & \\
\hline \multirow{4}{*}{$\begin{array}{c}\text { Geleneksel } \\
\text { Zanaat } \\
\text { Bilgisi }\end{array}$} & İlköğretim & 2,5935 & 1,01520 & \multirow{4}{*}{3,415} & \multirow{4}{*}{2,768} & \multirow{4}{*}{,018 } & \multirow{4}{*}{$\begin{array}{l}\text { Ön Lisans- } \\
\text { Lisans ve } \\
\text { Lisansüstü }\end{array}$} \\
\hline & Lise & 2,5405 & 1,07772 & & & & \\
\hline & Ön lisans & 2,3030 & 1,12535 & & & & \\
\hline & $\begin{array}{l}\text { Lisans ve } \\
\text { üstü }\end{array}$ & 2,9132 & 80129 & & & & \\
\hline
\end{tabular}

Varyans sonuçlarına göre ( $\mathrm{p}<0,05$ olduğu için) risk alma, belirsizliğe tolerans ve geleneksel zanaat bilgisi boyutları eğitim düzeyine göre anlamlı farklılık göstermektedir. Bu farklılığı 
ortaya koymak adına post hoc testi yapılmıştır. Post hoc testi sonuçlarına bakıldığında; risk alma boyutu için ilköğretim mezunları ile lise ve ön lisans mezunları arasında anlamlı farklılık bulunmaktadır. Buna göre ortalama değerlere bakıldığında ön lisans mezunu katılımcıların lise ve ilköğretim mezunu katılımcılara kıyasla daha fazla; lise mezunlarının da ilköğretim mezunlarına göre daha fazla risk aldığı görülmektedir. En yüksek ortalamayla risk alan grup ön lisans mezunları olurken en az ortalamayla risk alan grup ilköğretim mezunları olmuştur. Lisans ve lisansüstü olan esnafların ortalaması ise ilköğretim mezunlarından daha çok fakat lise ve ön lisans mezunlarından daha azdır. Diğer taraftan eğitim düzeyi arttıkça katılımcıların belirsizliğe toleransları artmaktadır. Post hoc testi sonuçlarına göre, belirsizliğe toleransın en fazla ortalamaya sahip olduğu grup lisans ve lisansüstü eğitim alanlardır. Geleneksel zanaat bilgisi boyutunun eğitim düzeyine göre farklılığının ön lisans mezunları ile lisans mezunu katılımcılar arasında olduğu sonucuna ulaşılmıştır. Post hoc testi sonuçlarına göre, lisans mezunu katılımcıların ön lisans mezunu katılımcılara göre daha fazla geleneksel zanaat bilgisiyle hareket ettikleri görülmüştür. Ön lisans mezunları diğer mezun gruplarında yer alan esnaflara göre en düşük düzeyde geleneksel zanaat bilgisiyle işlerini yaparken, lisans ve lisansüstü mezuniyeti olan katılımcılar en yüksek düzeyde geleneksel zanaat bilgisiyle işlerini yapmaktadırlar. Böylece çalışmanın $\mathrm{H}_{2}$ risk alma, belirsizliğe tolerans ve geleneksel zanaat bilgisi boyutunda desteklenmiş, diğer boyutlarda desteklenmemiştir.

\subsection{2. İşletme Özelliklerinin Girişimci Kişilik Özelliği Boyutlarıyla İlişkisinin Analizi}

Çalışmanın bu bölümünde anket formunun ilk kısmında yer alan, katılımcı esnafların işletmelerinin özelliklerinin, onların girişimci kişilik özelliği boyutlarıyla ilişkisi yer almaktadır. Girişimcilik alt boyutlarının işletmenin içerisinde yer aldığ1 sektöre ilişkin farklılıkları Tablo 9'da gösterilmektedir.

Tablo 9. Girişimcilik Alt Boyutlarının Sektöre İlişkin Farklı1ıkları

\begin{tabular}{|c|c|c|c|c|c|c|c|}
\hline Boyut & Sektör & $\begin{array}{c}\text { Ortalama } \\
\text { (x) }\end{array}$ & $\begin{array}{c}\text { Standart } \\
\text { Sapma }\end{array}$ & $\mathbf{F}$ & $\begin{array}{c}\text { Levene } \\
\text { Testi } \\
\text { Anl. }\end{array}$ & $\begin{array}{l}\text { Sig } \\
\text { (p) }\end{array}$ & Fark \\
\hline \multirow{6}{*}{$\begin{array}{l}\text { Başarı } \\
\text { İhtiyacı }\end{array}$} & Tekstil & 4,6441 & ,39825 & \multirow{6}{*}{,113 } & \multirow{6}{*}{,285 } & \multirow{6}{*}{,989 } & \multirow{6}{*}{ - } \\
\hline & Gida & 4,6000 & 42700 & & & & \\
\hline & Otomotiv & 4,6514 & ,40683 & & & & \\
\hline & Ayakkabıcılık & 4,6333 & ,36013 & & & & \\
\hline & Kuyumculuk & 4,6000 & ,41039 & & & & \\
\hline & Diğer & 4,6218 & ,41037 & & & & \\
\hline \multirow{6}{*}{ Risk Alma } & Tekstil & 2,7540 & 1,03243 & \multirow{6}{*}{2,866} & \multirow{6}{*}{, 584} & \multirow{6}{*}{,016 } & \multirow{6}{*}{$\begin{array}{l}\text { Tekstil- } \\
\text { Gıda- } \\
\text { Otomotiv }\end{array}$} \\
\hline & Gida & 2,7121 & ,95801 & & & & \\
\hline & Otomotiv & 3,4476 & 1,00957 & & & & \\
\hline & Ayakkabicilık & 2,7222 & ,99324 & & & & \\
\hline & Kuyumculuk & 2,8833 & ,84656 & & & & \\
\hline & Diğer & 2,8485 & 1,00578 & & & & \\
\hline \multirow{4}{*}{$\begin{array}{c}\text { Belirsizliğe } \\
\text { Tolerans }\end{array}$} & Tekstil & 2,2929 & ,82401 & \multirow{4}{*}{2,806} & \multirow{4}{*}{1,644} & \multirow{4}{*}{,017 } & \multirow{4}{*}{$\begin{array}{l}\text { Gida- } \\
\text { Otomotiv }\end{array}$} \\
\hline & Gida & 2,7364 & 1,05634 & & & & \\
\hline & Otomotiv & 2,0286 & ,87197 & & & & \\
\hline & Ayakkabıcılık & 2,3333 & ,99575 & & & & \\
\hline
\end{tabular}




\begin{tabular}{|c|c|c|c|c|c|c|c|}
\hline & Kuyumculuk & 2,4000 & ,77866 & & & & \\
\hline & Diğer & 2,2145 & 91801 & & & & \\
\hline \multirow{6}{*}{ Yenilik } & Tekstil & 3,6652 & 89333 & \multirow{6}{*}{3,400} & \multirow{6}{*}{1,641} & \multirow{6}{*}{,005 } & \multirow{6}{*}{$\begin{array}{c}\text { Gida- } \\
\text { Otomotiv }\end{array}$} \\
\hline & Gida & 3,3182 & 1,04907 & & & & \\
\hline & Otomotiv & 4,1143 & ,70915 & & & & \\
\hline & Ayakkabıcılık & 3,5556 & 83283 & & & & \\
\hline & Kuyumculuk & 3,6000 & 82788 & & & & \\
\hline & Diğer & 3,7394 & ,78748 & & & & \\
\hline \multirow{6}{*}{$\begin{array}{c}\text { Geleneksel } \\
\text { Zanaat } \\
\text { Bilgisi }\end{array}$} & Tekstil & 2,6905 & 1,05255 & \multirow{6}{*}{1,722} & \multirow{6}{*}{ 798 } & \multirow{6}{*}{ 130 } & \multirow{6}{*}{ - } \\
\hline & Gida & 2,9091 & ,99446 & & & & \\
\hline & Otomotiv & 2,5429 & 1,02289 & & & & \\
\hline & Ayakkabicılık & 2,0833 & ,94415 & & & & \\
\hline & Kuyumculuk & 2,4333 & 71000 & & & & \\
\hline & Diğer & 2,5455 & 1,04106 & & & & \\
\hline
\end{tabular}

Varyans sonuçlarına göre ( $\mathrm{p}<0,05$ olduğu için) risk alma, belirsizliğe tolerans ve yenilik boyutları esnafların faaliyette bulundukları sektöre göre anlamlı farklılık göstermektedir. $\mathrm{Bu}$ farklılığı ortaya koymak adına post hoc testi yapılmıştır. Post hoc testi sonuçlarına bakıldığında; risk alma boyutu için otomotiv, tekstil ve gida sektörleri arasında anlamlı farklılık bulunmaktadır. Risk alma eğilimi açısından en yüksek ortalama, katma değeri daha yüksek olan otomotiv sektöründe, tekstil sektöründe yer alan esnaflarda ve post hoc testinde çıkmamış olmakla beraber kuyumculuk sektöründeki esnaflarda görülürken, en düşük risk alma eğilimi ortalaması, diğer sektörlere göre ürün katma değerinin nispeten daha düşük olduğu, gida sektöründe yer alan esnaflarda görülmektedir. Post hoc testi sonuçlarına göre, benzer şekilde yenilikle ilgili boyutta da otomotiv sektöründeki esnafların ortalaması en yüksek, buna karşılık gıda sektöründeki esnafların ortalaması en düşüktür. Bu bağlamda, risk alma boyutu ile yenilik boyutundaki her iki sektör için görülen farklılaşma birbiriyle tutarlıdır. Çünkü yenilik nispeten risk almayı da gerektirmektedir. Ancak, belirsizliğe tolerans boyutundaki farklılaşma gıda sektöründeki esnaf ve otomotiv sektöründeki esnaf için tam tersi bir durum göstermektedir. Risk alma ve yenilik boyutlarında en yüksek ortalamaya sahip olan otomotiv sektöründeki esnafların belirsizliğe tolerans boyutundaki ortalaması en düşüuk değerde (2.03); risk alma ve yenilik boyutlarında en düşük ortalamaya sahip olan gıda sektöründeki esnafların belirsizliğe tolerans boyutundaki ortalamaları (2.74) ise en yüksek değerdedir. Bu durum girişimcilik eğilim beklentisi açısından bir tezatlık oluşturmaktadır. Çünkü literatürde de ifade edildiği gibi (Timuroğlu ve Çakır, 2014: 132) risk alan girişimcilerin belirsizliğe toleranslarının da olduğu düşünülmektedir. Ancak, anket çalışmasının yapıldığı (2020 Eylül-Ekim-Kasım-Aralık) pandemi dönemi dikkate alındı̆̆ında gıda sektöründeki ürünlerin otomotiv sektöründeki ürünlere göre daha elzem olması, otomotiv sektöründeki belirsizliği daha artırırken, gıda sektöründeki belirsizliği nispeten azaltmaktadır. Bu da gıda sektöründeki esnafların diğer sektörlere göre daha az belirsiz olan şartlardaki ve piyasadaki toleranslarının nispeten fazla olduğu algılarına yol açmaktadır. Gıda sektörü gibi elzem olmayan, üstelik katma değeri yüksek ürünlerin yer aldığı dolayısıyla da belirsizliğin nispeten daha çok olduğu otomotiv sektöründe yer alan esnafların ise ayakta durabilmeleri için daha fazla risk almaları ve yenilik eğiliminde olmalarını fark etmelerine rağmen belirsizliğe tolerans algılarını düşük tuttukları 
düşünülmektedir. Bu sonuçlara göre $\mathrm{H}_{3}$ risk alma, belirsizliğe tolerans ve yenilik boyutunda desteklenmiş, diğer boyutlarda desteklenmemiştir.

Girişimcilik alt boyutlarının işletmelerin kuruluş yıllarına ilişkin farklılıkları Tablo 10'da gösterilmektedir.

Tablo 10. Girişimcilik Alt Boyutlarının İşletmelerin Kuruluş Yıllarına İlişkin Farklılıkları

\begin{tabular}{|c|c|c|c|c|c|c|c|}
\hline Boyut & Y11 & $\begin{array}{c}\text { Ortalama } \\
(\mathrm{x})\end{array}$ & $\begin{array}{c}\text { Standart } \\
\text { Sapma }\end{array}$ & $\mathbf{F}$ & $\begin{array}{c}\text { Levene } \\
\text { Testi Anl. }\end{array}$ & $\begin{array}{l}\text { Sig } \\
\text { (p) }\end{array}$ & Fark \\
\hline \multirow{6}{*}{$\begin{array}{c}\text { Başarı } \\
\text { İhtiyacı }\end{array}$} & 1980 öncesi & 4,6412 & ,42577 & \multirow{6}{*}{,332 } & \multirow{6}{*}{1,651} & \multirow{6}{*}{894} & \multirow{6}{*}{-} \\
\hline & 1980-1989 & 4,6519 & ,40227 & & & & \\
\hline & $1990-1999$ & 4,6261 & 33739 & & & & \\
\hline & 2000-2009 & 4,6022 & ,42913 & & & & \\
\hline & $2010-2015$ & 4,7023 & ,33344 & & & & \\
\hline & $\begin{array}{l}2016 \text { ve } \\
\text { sonrasi }\end{array}$ & 4,6215 & ,41702 & & & & \\
\hline \multirow{6}{*}{ Risk Alma } & 1980 öncesi & 2,6078 & ,90069 & \multirow{6}{*}{1,746} & \multirow{6}{*}{,954 } & \multirow{6}{*}{,125 } & \multirow{6}{*}{-} \\
\hline & 1980-1989 & 2,6420 & 96044 & & & & \\
\hline & $1990-1999$ & 2,7536 & 1,12014 & & & & \\
\hline & $2000-2009$ & 2,8188 & ,89085 & & & & \\
\hline & $2010-2015$ & 3,1705 & 1,09441 & & & & \\
\hline & $\begin{array}{l}2016 \text { ve } \\
\text { sonrası }\end{array}$ & 2,9897 & 1,07847 & & & & \\
\hline \multirow{6}{*}{$\begin{array}{c}\text { Belirsizliğe } \\
\text { Tolerans }\end{array}$} & 1980 öncesi & 2,4647 & ,92076 & \multirow{6}{*}{ 786 } & \multirow{6}{*}{1,720} & \multirow{6}{*}{, 561} & \multirow{6}{*}{-} \\
\hline & 1980-1989 & 2,4444 & ,78119 & & & & \\
\hline & 1990-1999 & 2,2261 & ,75632 & & & & \\
\hline & $2000-2009$ & 2,1304 & ,78340 & & & & \\
\hline & 2010-2015 & 2,4047 & 1,06859 & & & & \\
\hline & $\begin{array}{l}2016 \text { ve } \\
\text { sonrasi }\end{array}$ & 2,3077 & ,99189 & & & & \\
\hline \multirow{6}{*}{ Yenilik } & 1980 öncesi & 3,3824 & ,92526 & \multirow{6}{*}{2,636} & \multirow{6}{*}{,151 } & \multirow{6}{*}{,024 } & \multirow{6}{*}{$\begin{array}{c}\text { Bütün } \\
\text { yıllar } \\
\text { arasında }\end{array}$} \\
\hline & 1980-1989 & 3,2963 & 1,02671 & & & & \\
\hline & 1990-1999 & 3,6812 & ,92920 & & & & \\
\hline & 2000-2009 & 3,6495 & ,81045 & & & & \\
\hline & $2010-2015$ & 3,8450 & ,84937 & & & & \\
\hline & $\begin{array}{l}2016 \text { ve } \\
\text { sonrasi }\end{array}$ & 3,8615 & 85572 & & & & \\
\hline \multirow{6}{*}{$\begin{array}{c}\text { Geleneksel } \\
\text { Zanaat } \\
\text { Bilgisi }\end{array}$} & 1980 öncesi & 2,6765 & ,99319 & \multirow{6}{*}{,661 } & \multirow{6}{*}{ 654 } & \multirow{6}{*}{ 653 } & \multirow{6}{*}{-} \\
\hline & 1980-1989 & 2,8765 & 1,03009 & & & & \\
\hline & 1990-1999 & 2,7681 & 1,05138 & & & & \\
\hline & $2000-2009$ & 2,5072 & 94474 & & & & \\
\hline & $2010-2015$ & 2,5116 & 1,10158 & & & & \\
\hline & $\begin{array}{l}2016 \text { ve } \\
\text { sonrasi }\end{array}$ & 2,6462 & 1,02211 & & & & \\
\hline
\end{tabular}

Varyans sonuçlarına göre $(\mathrm{p}<0,05)$ olduğu için sadece yenilik boyutu işletmelerin kuruluş yıllarına göre farklılık göstermektedir. Bu farklılığı ortaya koymak adına post hoc testi yapılmıştır. Post hoc testi sonuçlarına bakıldığında; elde edilen ortalama değerlere ilişkin 
günümüze doğru kurulan işletmelerin daha fazla yenilikçi değerleri benimsediği sonucuna ulaşılmıştır. Her ne kadar liberal politikalara 1980 yılından itibaren geçilmişse de pazarda ve üründe yenilenmenin daha somut olduğu dönem 1990'lı yıllarla başlamıştır. 2010 yılından itibaren ise hızlanan internet alt yapısıyla beraber, üründe, üretim süreçlerinde, pazarda, hizmet süreçlerinde, müşteri ve işletme arasındaki ilişkilerin şekillenmesinde yenilik uzun dönemde var olmanın ve sürdürülebilir rekabetin vazgeçilemez unsuru haline gelmiştir. Esnafların da internet kullanımını artırmalarıyla beraber, hem ürünlerin dünya pazarındaki değişimini görme hem de tedarik ve pazarlama tekniklerini yenileme konusunda (internetten sipariş, internetten satış, internet üzerinde reklamla daha geniş kitleye ulaşma vb.) fırsatları artmıştır. Tablo 10'da görüldüğü üzere yıllar itibariyle diğer boyutlarda herhangi bir farklılaşma olmamakla beraber, yenilik boyutunda her yıl için fakat özellikle 2010 yılı sonrası için dikkate değer bir farklılaşma olduğu görülmektedir. Elde edilen sonuçlara göre $\mathrm{H}_{4}$ yenilik boyutunda desteklenmiş diğer boyutlarda desteklenmemiştir.

Girişimcilik alt boyutlarının işletmelerin hâlihazırdaki mülkiyetine ilişkin farklılıkları Tablo 11 'de gösterilmektedir.

Tablo 11. Girişimcilik Alt Boyutlarının İşletmelerin Hâlihazırdaki Mülkiyetine İlişkin Farklılıkları

\begin{tabular}{|c|c|c|c|c|c|c|c|}
\hline Boyut & Mülkiyet Durumu & $\begin{array}{l}\text { Ortalama } \\
\text { (x) }\end{array}$ & $\begin{array}{l}\text { Standart } \\
\text { Sapma }\end{array}$ & $\mathbf{F}$ & $\begin{array}{l}\text { Levene } \\
\text { Testi } \\
\text { Anl. }\end{array}$ & $\begin{array}{l}\text { Sig } \\
\text { (p) }\end{array}$ & Fark \\
\hline \multirow{3}{*}{$\begin{array}{c}\text { Başarı } \\
\text { İhtiyacı }\end{array}$} & $\begin{array}{c}\text { Mülkiyeti } \\
\text { tamamen bana } \\
\text { aittir. } \\
\end{array}$ & 4,6222 & 40290 & \multirow{3}{*}{,969 } & \multirow{3}{*}{,226 } & \multirow{3}{*}{,381 } & \multirow{3}{*}{-} \\
\hline & Aile ortaklığıdır. & 4,6000 & 41123 & & & & \\
\hline & $\begin{array}{l}\text { Aileden olmayan } \\
\text { kişi veya kişilerle } \\
\text { ortaklığı vardır. }\end{array}$ & 4,7077 & ,38620 & & & & \\
\hline \multirow{3}{*}{ Risk Alma } & $\begin{array}{c}\text { Mülkiyeti } \\
\text { tamamen bana } \\
\text { aittir. }\end{array}$ & 2,8830 & 1,05969 & \multirow{3}{*}{1,005} & \multirow{3}{*}{612} & \multirow{3}{*}{,367 } & \multirow{3}{*}{ - } \\
\hline & Aile ortaklığıdır. & 2,9542 & , 96455 & & & & \\
\hline & $\begin{array}{l}\text { Aileden olmayan } \\
\text { kişi veya kişilerle } \\
\text { ortaklığ } 1 \text { vardır. }\end{array}$ & 2,6752 & ,95049 & & & & \\
\hline \multirow{3}{*}{$\begin{array}{c}\text { Belirsizliğe } \\
\text { Tolerans }\end{array}$} & $\begin{array}{c}\text { Mülkiyeti } \\
\text { tamamen bana } \\
\text { aittir. }\end{array}$ & 2,3588 & ,93701 & \multirow[b]{3}{*}{6,219} & \multirow[b]{3}{*}{1,002} & \multirow[b]{3}{*}{,002 } & \multirow{3}{*}{$\begin{array}{c}\text { Mülkiyeti } \\
\text { tek bir } \\
\text { kişide- } \\
\text { Aile } \\
\text { ortaklığı- } \\
\text { Aileden } \\
\text { olmayan } \\
\text { kişilerle } \\
\text { ortaklık }\end{array}$} \\
\hline & Aile ortaklığıdır & 2,4925 & ,90172 & & & & \\
\hline & $\begin{array}{l}\text { Aileden olmayan } \\
\text { kişi veya kişilerle } \\
\text { ortaklığı vardır. }\end{array}$ & 1,8821 & 74511 & & & & \\
\hline Yenilik & $\begin{array}{c}\text { Mülkiyeti } \\
\text { tamamen bana } \\
\text { aittir. } \\
\end{array}$ & 3,6972 & ,88235 & , 109 & 1,238 & 897 & - \\
\hline
\end{tabular}




\begin{tabular}{|c|c|c|c|c|c|c|c|}
\hline & Aile ortaklığıdır. & 3,6526 & 86419 & & & & \\
\hline & $\begin{array}{l}\text { Aileden olmayan } \\
\text { kişi veya kişilerle } \\
\text { ortaklığı vardır. }\end{array}$ & 3,6325 & 99058 & & & & \\
\hline \multirow{3}{*}{$\begin{array}{c}\text { Geleneksel } \\
\text { Zanaat } \\
\text { Bilgisi }\end{array}$} & $\begin{array}{c}\text { Mülkiyeti } \\
\text { tamamen bana } \\
\text { aittir. }\end{array}$ & 2,6514 & 1,07167 & \multirow{3}{*}{,756 } & \multirow{3}{*}{1,573} & \multirow{3}{*}{,471 } & \multirow{3}{*}{ - } \\
\hline & Aile ortaklığıdır & 2,6750 & 89847 & & & & \\
\hline & $\begin{array}{c}\text { Aileden olmayan } \\
\text { kişi veya kişilerle } \\
\text { ortaklığı vardır. }\end{array}$ & 2,4444 & 1,05224 & & & & \\
\hline
\end{tabular}

Varyans sonuçlarına göre $(p<0,05)$ olduğu için belirsizliğe tolerans boyutu işletmelerin hâlihazırdaki mülkiyetlerine göre farklılık göstermektedir. Bu farklılı̆̆ı ortaya koymak adına post hoc testi yapılmıştır. Post hoc testi sonuçlarına göre ortalama değerlere bakıldığında; aile dışındaki bireylerle ortak olan katılımcıların belirsizliğe tolerans ifadelerinin ortalamalarının düşük olduğu görülmüştür. Tablo 11'in geneline bakıldığında da mülkiyetin dağılımı açısından diğer girişimcilikle ilgili boyutların (başarı ihtiyacı, risk alma, yenilik, geleneksel zanaat bilgisi) ortalaması genel olarak orta ya da düşük değere ( $\bar{x}=2,60-3,39$ Orta; $\bar{x}=3,40-5$ yüksek) sahipken, belirsizliğe tolerans boyutundaki değerlerin her biri düşük değere ( $\overline{x=1-2,59}$; düşük) sahiptir. Bu boyut kendi içerisinde değerlendirildiğinde de esnaflar işletmelerinin mülkiyetine tek başlarına sahiplerse ya da aile ortaklıkları varsa nispeten daha fazla belirsizliğe tolerans gösterirken, aileden olmayan kişi veya kişilerle ortaklıklarının olduğu durumda esnafların belirsizliğe toleransı önemli ölçüde düşmektedir. Ortaklık kültürünün yeterince güçlü olmadığı (Halis vd., 2009: 453-457) ve güven endeksi açısından kişilerin birbirlerine güvenlerinin düşük olduğu toplumlarda bu durum belirsizlik düzeyinin daha yüksek algılanmasına; belirsizliğe toleransın da daha düşük olmasına sebebiyet vermektedir. Literatürdeki bulgular da bu ifadeleri destekler niteliktedir. Nitekim 2010-2014 Dünya Değerler Araştırması'na katılan ülkeler arasında kişilerarası sosyal güvenin seviyesine göre Türkiye, güven yüzdesi yaklaşı \%11'le en düşük oranlı ülkeler arasında ve araştırmaya dâhil OECD ülkeleri arasında en düşük orana sahip ülke konumundadır (Aytaç vd., 2017: 5). Yine Ekonomi İşbirliği ve Kalkınma Örgütü tarafından hazırlanan 'How is Life in 2020?' raporunda sosyal ağların acil durumlarda destek sağlama kapasitesinin OECD ülkelerinin çoğunda güçlü göründüğü ifade edilmektedir. Bu ölçüme göre, OECD ülkeleri arasında destek ağlarının Türkiye, Kore, Portekiz ve Estonya'da en zayıf olduğu ve İzlanda, İrlanda, Yeni Zelanda ve Danimarka'da en güçlü olduğu sonucuna ulaşılmıştır (OECD, 2020: 174). Tablo 11'e göre, $\mathrm{H}_{5}$ sadece belirsizliğe tolerans boyutunda desteklenmiş diğer boyutlarda desteklenmemiştir.

Girişimcilik alt boyutlarının işletmelerde mamulün tedarik şekline ilişkin farklılıkları Tablo 12 'de gösterilmektedir. 
Tablo 12. Girişimcilik Alt Boyutlarının İşletmelerde Mamulün Tedarik Şekline İlişkin Farklılıkları

\begin{tabular}{|c|c|c|c|c|c|}
\hline Boyut & Tedarik Şekli & $\mathbf{N}$ & $\begin{array}{c}\text { Ortalama } \\
(x)\end{array}$ & $\begin{array}{l}\text { Standart } \\
\text { Sapma }\end{array}$ & Sig (p) \\
\hline \multirow{2}{*}{ Başarı İhtiyacı } & $\begin{array}{c}\text { Tedarik için kendimize } \\
\text { ait işletmemiz var }\end{array}$ & 50 & 4,6080 & ,37024 & \multirow[t]{2}{*}{690} \\
\hline & $\begin{array}{c}\text { Başka işletmelerden } \\
\text { satın alıyoruz. }\end{array}$ & 200 & 4,6335 & ,41153 & \\
\hline \multirow{2}{*}{ Risk Alma } & $\begin{array}{c}\text { Tedarik için kendimize } \\
\text { ait işletmemiz var }\end{array}$ & 50 & 2,8467 & ,93122 & \multirow[t]{2}{*}{,836 } \\
\hline & $\begin{array}{l}\text { Başka işletmelerden } \\
\text { satın alıyoruz. }\end{array}$ & 200 & 2,8800 & 1,03541 & \\
\hline \multirow{2}{*}{ Belirsizliğe Tolerans } & $\begin{array}{c}\text { Tedarik için kendimize } \\
\text { ait işletmemiz var. }\end{array}$ & 50 & 2,6600 & ,95640 & \multirow[t]{2}{*}{,004 } \\
\hline & $\begin{array}{c}\text { Başka işletmelerden } \\
\text { satın alıyoruz. }\end{array}$ & 200 & 2,2440 & 89041 & \\
\hline \multirow{2}{*}{ Yenilik } & $\begin{array}{c}\text { Tedarik için kendimize } \\
\text { ait işletmemiz var }\end{array}$ & 50 & 3,5733 & 87557 & \multirow[t]{2}{*}{,378 } \\
\hline & $\begin{array}{l}\text { Başka işletmelerden } \\
\text { satın alıyoruz. }\end{array}$ & 200 & 3,6977 & 89524 & \\
\hline \multirow{2}{*}{$\begin{array}{c}\text { Geleneksel Zanaat } \\
\text { Bilgisi }\end{array}$} & $\begin{array}{c}\text { Tedarik için kendimize } \\
\text { ait işletmemiz var }\end{array}$ & 50 & 2,9000 & 1,02409 & \multirow[t]{2}{*}{,033 } \\
\hline & $\begin{array}{l}\text { Başka işletmelerden } \\
\text { satın alıyoruz. }\end{array}$ & 200 & 2,5583 & 1,00414 & \\
\hline
\end{tabular}

Bağımsız $t$ testi sonuçlarına göre göre $p<0,05$ olduğu için belirsizliğe tolerans ve geleneksel zanaat bilgisi, işletmelerin mamullerinin tedarik şekline göre farklılık göstermektedir. $\mathrm{Bu}$ farklılığı ortaya koymak adına post hoc testi yapılmıştır. Post hoc testi sonuçlarına göre ortalama değerlere ilişkin; satışını yaptığı mamulün üretimini yapan işletmeye sahip olan esnafların, mamulü başka işletmelerden satın alan esnaflara göre geleneksel zanaat bilgisi kullanma düzeylerinin yüksek olduğu sonucuna ulaşılmıştır. Bu durum geleneksel zanaat bilgisinin üretim aşamasından itibaren devam ettiğinin de bir göstergesidir. Zaten tedariklerini kendi işletmelerinden karşılayan esnafların belirsizliğe toleransları da tedariklerini başka işletmelerden karşılayan esnaflara göre daha yüksek çıkmıştır. Çünkü tedariklerini kendi işletmelerinden karşılayan işletmelerin tedarik açısından belirsizlik ortamları daha düşük olmakta dolayısıyla nispeten düşük düzeyde olan belirsizliğe daha yüksek tolerans algısı gösterilebilmektedir. Tedarik faaliyetini başka işletmelerden karşılayan esnafların ise diğer grup esnaflara göre tedarik belirsizlikleri daha yüksek olmakta, dolayısıyla daha yüksek belirsizliği tolere etme durumları düşebilmektedir. Böylece çalışmanın $\mathrm{H}_{6}$ belirsizliğe tolerans ve geleneksel zanaat bilgisi boyutunda desteklenmiş, diğer boyutlarda desteklenmemiştir.

Girişimcilik alt boyutlarının işletmelerde mamulün tedarik şekline ilişkin farklılıkları Tablo 13 'de gösterilmektedir. 
Tablo 13. Girişimcilik Alt Boyutlarının İşletmenin Katılımcıların Mülkiyetinde Olduğu Dönemde Büyümesine İlişkin Farklılıkları

\begin{tabular}{|c|c|c|c|c|c|}
\hline Boyut & Büyüme & $\mathbf{N}$ & Ortalama (x) & $\begin{array}{c}\text { Standart } \\
\text { Sapma }\end{array}$ & Sig (p) \\
\hline \multirow{2}{*}{ Başarı İhtiyacı } & Evet & 207 & 4,6440 & ,39170 & \multirow{2}{*}{ 181 } \\
\hline & Hayır & 43 & 4,5535 & ,45111 & \\
\hline \multirow{2}{*}{ Risk Alma } & Evet & 207 & 2,9372 & ,99450 & \multirow{2}{*}{029} \\
\hline & Hayır & 43 & 2,5659 & 1,06044 & \\
\hline \multirow{2}{*}{ Belirsizliğe Tolerans } & Evet & 207 & 2,3826 & ,93211 & \multirow{2}{*}{,036 } \\
\hline & Hayır & 43 & 2,0605 & ,79945 & \\
\hline \multirow{2}{*}{ Yenilik } & Evet & 207 & 3,7450 & 84241 & \multirow{2}{*}{,005 } \\
\hline & Hayır & 43 & 3,3256 & 1,03762 & \\
\hline \multirow{2}{*}{ Geleneksel Zanaat Bilgisi } & Evet & 207 & 2,6699 & 1,02398 & \multirow{2}{*}{140} \\
\hline & Hayır & 43 & 2,4186 & ,95699 & \\
\hline
\end{tabular}

Bağımsız $\mathrm{t}$ testi sonuçlarına göre ( $\mathrm{p}<0,05$ olduğu için) olduğu için; risk alma, belirsizliğe tolerans ve yenilik boyutlarında katılımcıların işletmelerinin kendi mülkiyetlerinde olduğu dönemde büyüme gösterip göstermediğine göre farklılık bulunmuştur. Buna göre ortalama değerlere bakıldığında; işletmesi büyüme gösteren esnafların daha fazla riske katlandığı ve daha fazla yenilikçi faaliyetlerde bulunduğu görülmektedir. Daha fazla riske katlanarak ve daha fazla yenilik eğilimi göstererek büyüyen işletmelerin esnaflarının bütün bu süreç içerisinde riskin ve yeniliğin kabul edilme sürecindeki belirsizliğe tolerans göstermeleri gerekmektedir. Tablo 13'te görüldüğü üzere işletmelerinde büyüme gösteren esnafların belirsizliğe toleransları da işletmeleri büyümeyen esnaflara göre daha yüksektir. Bu sonuçlara göre $\mathrm{H}_{7}$ risk alma, belirsizliğe tolerans ve yenilik boyutunda desteklenmiş diğer boyutlarda desteklenmemiştir.

Girişimcilik alt boyutlarının mamulün tedarik şekline ilişkin farklılıkları Tablo 14'de gösterilmektedir.

Tablo 14. Girişimcilik Alt Boyutlarının Katılımcıların İşletmelerini Gelecekte Büyütme Durumuna İlişkin Farklılıkları

\begin{tabular}{|c|c|c|c|c|c|}
\hline Boyut & $\begin{array}{l}\text { Gelecekte } \\
\text { Büyütme } \\
\text { Durumu }\end{array}$ & $\mathbf{N}$ & Ortalama (x) & $\begin{array}{l}\text { Standart } \\
\text { sapma }\end{array}$ & $\operatorname{Sig}(p)$ \\
\hline \multirow{2}{*}{ Başarı İhtiyacı } & Evet & 203 & 4,6355 & ,39542 & \multirow{2}{*}{, 566} \\
\hline & Hayır & 47 & 4,5979 & ,43756 & \\
\hline \multirow{2}{*}{ Risk Alma } & Evet & 203 & 2,9951 & 99143 & \multirow{2}{*}{,000 } \\
\hline & Hayır & 47 & 2,3475 & ,94781 & \\
\hline \multirow{2}{*}{$\begin{array}{l}\text { Belirsizliğe } \\
\text { Tolerans }\end{array}$} & Evet & 203 & 2,3793 & ,93733 & \multirow{2}{*}{,062 } \\
\hline & Hayır & 47 & 2,1021 & 79550 & \\
\hline \multirow{2}{*}{ Yenilik } & Evet & 203 & 3,7712 & 82727 & \multirow{2}{*}{,000 } \\
\hline & Hayır & 47 & 3,2482 & 1,03202 & \\
\hline \multirow{2}{*}{$\begin{array}{c}\text { Geleneksel Zanaat } \\
\text { Bilgisi }\end{array}$} & Evet & 203 & 2,6700 & 1,02980 & \multirow{2}{*}{, 162 } \\
\hline & Hayır & 47 & 2,4397 & ,93795 & \\
\hline
\end{tabular}


Bağımsız $\mathrm{t}$ testi sonuçlarına göre ( $\mathrm{p}<0,05$ olduğu için) risk alma ve yenilik boyutları, esnafların işletmelerini gelecekte büyütme durumlarına göre farklılık görülmektedir. Buna göre ortalama değerlere bakıldığında; işletmelerini gelecekte büyüteceğine inanan esnafların, bu duruma inanmayan esnaflara kıyasla risk alma ve yenilikçi özelliklerinin yüksek olduğu görülmüştür. Bu durum da üstteki tablonun (Tablo 13) verilerini destekler niteliktedir. Mevcut durumda işletmesini büyüten esnafların risk alma ve yenilik eğilimleri yüksek olduğu gibi işletmesini gelecekte de büyütmek isteyen esnafların risk alma ve yenilik eğilimleri diğer esnaf grubuna göre yüksek çıkmıştır. Bu sonuçlara göre $\mathrm{H}_{8}$ risk alma ve yenilik boyutunda desteklenmiş diğer boyutlarda desteklenmemiştir.

Tablo 15. Girişimcilik Alt Boyutlarının İşletmelerde Çalışan Sayısına İlişkin Farklılıkları

\begin{tabular}{|c|c|c|c|c|c|c|}
\hline Boyut & Çalışan Sayısı & Ortalama (x) & $\begin{array}{c}\text { Standart } \\
\text { Sapma }\end{array}$ & $\mathbf{F}$ & $\begin{array}{c}\text { Levene Testi } \\
\text { Anl. }\end{array}$ & $\operatorname{Sig}(p)$ \\
\hline \multirow{7}{*}{ Başarı İhtiyacı } & Çalışanım yok & 4,6605 & 39330 & \multirow{7}{*}{1,055} & \multirow{7}{*}{, 528} & \multirow{7}{*}{,390 } \\
\hline & 1 kişi & 4,6615 & ,43807 & & & \\
\hline & 2 kişi & 4,6100 & ,41250 & & & \\
\hline & 3 kişi & 4,4779 & ,39636 & & & \\
\hline & 4 kişi & 4,6222 & ,35277 & & & \\
\hline & 5 kişi & 4,5091 & ,44149 & & & \\
\hline & $5+$ & 4,6792 & ,38202 & & & \\
\hline \multirow{7}{*}{ Risk Alma } & Çalışanım yok & 2,7851 & 1,10044 & \multirow{7}{*}{600} & \multirow{7}{*}{443} & \multirow{7}{*}{,730 } \\
\hline & 1 kişi & 3,0769 & ,98367 & & & \\
\hline & 2 kişi & 2,9750 & ,97369 & & & \\
\hline & 3 kişi & 2,6914 & ,96044 & & & \\
\hline & 4 kişi & 2,9630 & 88889 & & & \\
\hline & 5 kişi & 2,7576 & 1,09637 & & & \\
\hline & $5+$ & 2,8750 & ,98121 & & & \\
\hline \multirow{7}{*}{$\begin{array}{l}\text { Belirsizliğe } \\
\text { Tolerans }\end{array}$} & Çalışanım yok & 2,0184 & ,73697 & \multirow{7}{*}{3,340} & \multirow{7}{*}{2,002} & \multirow{7}{*}{,004 } \\
\hline & 1 kişi & 2,3590 & 1,03434 & & & \\
\hline & 2 kişi & 2,3250 & 1,08006 & & & \\
\hline & 3 kişi & 2,3704 & ,84980 & & & \\
\hline & 4 kişi & 2,4444 & 83533 & & & \\
\hline & 5 kişi & 3,0182 & ,90534 & & & \\
\hline & $5+$ & 2,5875 & ,85194 & & & \\
\hline \multirow{7}{*}{ Yenilik } & Çalışanım yok & 3,6272 & ,92210 & \multirow{7}{*}{1,289} & \multirow{7}{*}{891} & \multirow{7}{*}{,263 } \\
\hline & 1 kişi & 3,6838 & ,96715 & & & \\
\hline & 2 kişi & 3,8917 & ,87507 & & & \\
\hline & 3 kişi & 3,4646 & ,94329 & & & \\
\hline & 4 kişi & 3,1481 & ,66898 & & & \\
\hline & 5 kişi & 3,7273 & ,59289 & & & \\
\hline & $5+$ & 3,7569 & 82725 & & & \\
\hline \multirow{7}{*}{$\begin{array}{c}\text { Geleneksel } \\
\text { Zanaat Bilgisi }\end{array}$} & Çalışanım yok & 2,3333 & ,95685 & \multirow{7}{*}{2,123} & \multirow{7}{*}{,838 } & \multirow{7}{*}{051} \\
\hline & 1 kişi & 2,7009 & 1,12597 & & & \\
\hline & 2 kişi & 2,6833 & 1,04854 & & & \\
\hline & 3 kişi & 2,5679 & ,93285 & & & \\
\hline & 4 kişi & 3,1481 & 1,08155 & & & \\
\hline & 5 kişi & 2,9091 & 1,00101 & & & \\
\hline & $5+$ & 2,8542 & ,94758 & & & \\
\hline
\end{tabular}


Varyans sonuçlarına göre ( $<<0,05$ olduğu için) sadece belirsizliğe tolerans boyutu işletmelerde çalışan sayısına göre farklılık göstermektedir. Bu farklılığı ortaya koymak adına post hoc testi yapılmıştır. Post hoc testi sonuçlarına bakıldığında; belirsizliğe toleransın en düşük olduğu esnaf grubu hiç çalışanının olmadığı yani her işi kendisinin yaptığı gruptur. Çalışan sayısı 5'e kadar arttıkça esnaflar belirsizliğe daha fazla tolerans gösterebilmektedirler. $\mathrm{Bu}$ sonuçlara göre $\mathrm{H}_{9}$ sadece belirsizliğe tolerans boyutunda desteklenmiş diğer boyutlarda desteklenmemiştir.

Girişimcilik alt boyutlarının son bir yıl içerisinde pandemi nedeniyle küçülmeye giden işletmelere ilişkin farklılıklar Tablo $16^{\prime}$ da gösterilmektedir.

Tablo 16. Girişimcilik Alt Boyutlarının Son 1 Yıl İçerisinde Pandemi Nedeniyle Küçülmeye Giden İşletmelere İlişkin Farklılıkları

\begin{tabular}{|c|c|c|c|c|c|}
\hline Boyut & $\begin{array}{l}\text { İşletmenin } \\
\text { Küçülme } \\
\text { Durumu }\end{array}$ & $\mathbf{N}$ & Ortalama $(\mathrm{x})$ & $\begin{array}{c}\text { Standart } \\
\text { Sapma }\end{array}$ & $\begin{array}{l}\text { Sig } \\
\text { (p) }\end{array}$ \\
\hline \multirow{2}{*}{ Başarı İhtiyacı } & Evet & 127 & 4,5914 & ,41593 & \multirow{2}{*}{, 140 } \\
\hline & Hayır & 123 & 4,6667 & ,38723 & \\
\hline \multirow{2}{*}{ Risk Alma } & Evet & 127 & 3,0052 & 1,04315 & \multirow{2}{*}{,036 } \\
\hline & Hayır & 123 & 2,7371 & 96784 & \\
\hline \multirow{2}{*}{ Belirsizliğe Tolerans } & Evet & 127 & 2,1890 & ,88454 & \multirow{2}{*}{,015 } \\
\hline & Hayır & 123 & 2,4699 & ,93212 & \\
\hline \multirow{2}{*}{ Yenilik } & Evet & 127 & 3,7576 & ,90933 & \multirow{2}{*}{,127 } \\
\hline & Hayır & 123 & 3,5854 & 86665 & \\
\hline \multirow{2}{*}{ Geleneksel Zanaat Bilgisi } & Evet & 127 & 2,4856 & ,96933 & \multirow{2}{*}{,025 } \\
\hline & Hayır & 123 & 2,7724 & 1,04482 & \\
\hline
\end{tabular}

Bağımsız t testi sonuçlarına göre; risk alma, belirsizliğe tolerans ve geleneksel zanaat bilgisi boyutları ile farklılık bulunmuştur. Elde edilen bulgulara göre pandemi döneminde küçülmeye giden işletmelerin risk alma eğilimleri daha yüksekken, geleneksel zanaat bilgisi yüksek olan esnafların küçülmeye gitmediği görülmüştür. Buna göre ortalamalar değerlendirildiğinde, pandemi döneminde risk alan esnafların işletmelerinde küçülme stratejisi uyguladıkları görülmüştür. Bununla beraber küçülmeye giden işletme esnaflarının belirsizliğe toleransları daha düşükken, işletmelerinde küçülmeye gitmeyen esnafların belirsizliğe toleransları daha yüksektir. Muhtemeldir ki pandemi döneminde ve sonrasında belirsizliği tolere etmek istemeyen girişimci esnaflar küçülmeye gitmenin riskini göze alarak kendilerini daha uzun dönemde yaşanabilecek belirsizliğe karşı korumaya almışlardır. Geleneksel zanaat bilgisi boyutu incelendiğinde de görülecektir ki küçülmeye giden işletme esnaflarının geleneksel zanaat bilgisi düşük seviyedeyken (2.48), pandemi döneminde işletmelerinde küçülme stratejisi uygulamayan işletmelerin geleneksel zanaat bilgisi nispeten daha yüksek olup orta düzeydedir (2.77). Bu da göstermektedir ki esnaflar geçmiş tecrübelere dayalı geleneksel zanaat bilgisini kullanarak belirsizliği daha fazla tolere etmekte ve küçülme ihtiyacı duymamaktadırlar. Böylece $\mathrm{H}_{10}$ risk alma, belirsizliğe tolerans ve geleneksel zanaat bilgisi boyutunda desteklenmiş diğer boyutlarda desteklenmemiştir. 


\section{TARTIŞMA VE SONUÇ}

Ekonomik kalkınmanın anahtarı olarak görülen girişimcilik süreci ve bu sürecin ana aktörü olan girişimciler ülkelerin gelişmesi için önemli bir kaynak olarak görülür. Ülkelerin ekonomik gelişiminde katalizör olan girişimciler ve girişimcilik faaliyetleri sermayenin tabana yayılması, dolaylı olarak sosyal gelişimin sağlanması ve demokrasinin yaygınlaşmasında önemli rol oynarlar. Bu durum, ülkelerin ekonomik ve sosyal açıdan gelişimine katkı sağlayan girişimcilerin farklı açılardan araştırılması gerekliliğini doğurmuştur. Ancak, sermayenin tabana yayılmasında ve büyük girişimlerin özellikle tedarik ve pazar açısından tamamlanmasındaki işleviyle de ekonomik hayatta önemli bir yeri olan; girişimsel sürecin vazgeçilmez halkasını oluşturan esnafların bir girişimci olarak literatürde kapsadığı alan kısıtlılık göstermektedir. Hâlbuki esnaflar, sermayelerini ortaya koyarak, yatırım yaparak, risk alarak, yenilik yaparak, istihdam imkânları yaratarak, iş birlikleri yaparak girişimciliğin bütün vasıflarını göstermektedirler.

$\mathrm{Bu}$ çalışmanın amacı esnafların girişimcilik özelliklerini ortaya koymak ve bu özellikleri analiz etmek olarak belirlenmiştir. Çalışmanın ilk bölümünde girişimci ve girişimcilik kavramlarının tarihsel süreçteki durumu incelenmiş ve girişimcilik özellikleri analiz edilmiştir. Girişimci tipolojisi açıklanmış, bu bağlamda esnaf girişimci kavramı hakkında bilgi verilmiştir.

Araştırmanın ikinci bölümünde esnafların sosyo-demografik özellikleri, kurdukları işletmenin özellikleri ve girişimcilik özelliklerine yönelik gerçekleştirilen alan araştırması yer almaktadır. Çalışmanın evrenini Denizli ili tarihinin günümüze kadar uzanan sürecinde ticaret merkezi olarak kabul edilen ve Denizli sanayisinin yerel piyasaya açılmasında köprü olduğu kabul edilen Bayramyeri esnafları oluşturmaktadır. Alan araştırmasında veri toplama tekniği olarak anket kullanılmış ve 250 esnaf ile anket yapılmıştır. Elde edilen veriler istatistiksel veri analizi paket programı aracılığıyla analiz edilmiştir. Verilerin güvenilirliği için cronbach's alpha değeri ölçülmüş, geçerlilik analizinin test edilmesi için ise faktör analizi yapılmıştır. Ortaya çıkan faktörler normallik testlerine tabi tutulmuş; normal dağılım sergiledikleri bilgisine ulaşılmıştır. Araştırmanın hipotezlerini test etmek için ise $t$ testi ve anova testi kullanılmıştır.

Çalışmada işletmenin mülkiyeti kendisine ait olan esnafların $(\% 52,4)$ yanında, aile ortaklı̆̆ına sahip olan esnaf işletmelerinin de (\%32) olduğu gözlenmiştir (Tablo 4). Aileden olmayan kişilerle ortaklık kurma durumu diğerlerine oranla oldukça azdır (\%15). Bu durum girişimciliği etkileyen kültürel iklimle açıklanabilir. Bir başka açıdan ise ailenin sahip olduğu girişimcilik kültürü girişimciliği ve profesyonelleşmeyi etkilemektedir. Türk kültüründe ortaklaşa davranış açısından yüksek toplulukçu değere sahip bireyler kişilerarası yakın ilişkilere, aile ve akraba ilişkilerine önem vermektedir. Bu durum aile kurumuna bağlı faaliyet gösteren işletmeler için geleneksel ortaklığ olumlu etkilerken öte yandan girişimcilik faaliyetlerinin dışa kapalı gerçekleşmesine neden olmaktadır (Güler vd, 2016: 27).

Çalışmanın alan araştırması, tüm dünyayı etkisi altına alan COVID-19 sürecinde yapılmıştır. Söz konusu süreç sağlık alanında başta olmak üzere sosyal ve ekonomik anlamda olumsuz etkiler yaratmıştır. Ekonomik hayatın bir parçası olan esnaflar bu durumdan en çok etkilenen kesimlerden biridir. Yapılan çalışmada esnafların \%50,8'i pandemi döneminde küçülmeye gittiğini belirtmiştir. Araştırmanın yapıldığı Ekim-Kasım-Aralık 2020 döneminde 
küçülmeye gitmeyen esnaflar ise örneklemin \%49,2 sini oluşturmaktadır (Tablo 4). Salgın süresince sosyal mesafe zorunluluğu, kapalı ortamlarda yüksek risk bulunması ve sokağa çıkma yasă̆ı gibi etkenler, işyerlerinin uzun vadeli kapalı olmasına dolayısıyla esnafların ekonomik olarak zor durumda kalmalarına sebep olmuştur. Yaşanan gelişmeler yerel esnaftan yapılan alışverişin azalmasına neden olmuş bunun sonucunda işletmeler küçülmeye gitmiştir. Güven'in yapmış olduğu çalışmada da COVID-19 pandemi döneminde insanların eve kapanması sebebiyle işletmelerin küçülmeye gittiği ve e-ticarete yöneldikleri, ayrıca giyim ve aksesuar ürünleri ile lüks tüketim ürünlerinin talebinde bir azalmanın olduğu öne sürülmektedir (Güven, 2020: 265-266).

Araştırmada katılımcıların işletmelerinin devamlılı̆̆ını sağlamalarında etkili olduğunu düşündügü beş durumu yüzde olarak oranlamaları istenmiştir. Bu faktörler işletme sahibinin ahlâkı, piyasa ahlâkı, devlet katkısı ve etkisi, yenilikçi olmak ve değişikliklere ayak uydurmaktır (Tablo 5). Günümüzde küreselleşme ve ekonomik kalkınmayla birlikte ahlâk kavramı daha da önem kazanmıştır. Yapılan çalışmada katılımcılar işletmelerinin devamlılığının sağlanmasında en önemli unsuru işletme sahibinin ahlâkı olarak görmektedir. Bununla beraber esnaflar işletmelerinin devamlılığının sağlanmasında işletme sahibinin ahlâkının yanında piyasa ahlâkına da büyük ölçüde önem vermektedir. Türk üretim ve ticaret tarihine ve esnaf kültürüne damga vuran ahilik teşkilatı incelendiğinde de esnafların 'ahlâk' konusuna verdiği önemi anlamlandırmak mümkündür. Bu açıdan her yıl düzenli olarak ahilik haftası kutlamaları gerçekleştirilirken ahilik kültürünün değerleri günümüze taşınmaktadır (www.ticaret.gov.tr). Denizli' de de gerçekleştirilen bu kutlamalar araştırmanın yapıldığı Bayramyerinde gerçekleşmektedir. Çalışmadan elde edilen bulgular, günümüz dünyasında daha çok üzerinde durulması gereken bir unsur olan ahlâk kavramının esnaflar için önemini açıklar niteliktedir.

Ekonomide önemli bir dağılım gösteren esnaflar için devlet katkısının ve etkisinin önemli olması gerekirken, araştırma bulguları katılımcıların işletmelerinin sürekliliği için devlet katkısını ve etkisini düşük düzeyde algıladıklarını göstermektedir (Tablo 5). Bu durumun çeşitli nedenleri olabileceği gibi literatür incelendiğinde; yapılan bir çalışmada esnafların sorunları arasında en dikkat çeken konunun devlete ödenen vergi unsuru olduğu görülmüştür. Sermayesi kısıtlı olan esnaflar vergi oranlarının yüksek olduğunu, vergi dağılımının adaletsiz olduğunu ve denetimin yetersiz olduğunu düşünmektedirler (Çam ve Kabadayı, 2017: 107). Yapılan başka bir çalışmada ise esnafların kriz zamanlarında başvurdukları ilk kaynağın kendi birikimleri olduğu ikinci olarak aileye borçlanma şeklinde olduğu sonucuna ulaşılmıştır. Devlete başvurma seçeneği ise kriz zamanlarında bu kaynaklardan sonra gelmektedir (Akçakaya ve Bağrıyanık, 2019: 334).

Katılımcımlar ekonomik hayattaki gelişmede ve işletmenin devamlılı̆̆ının sağlanmasında yenilikçi olmanın ve değişikliklere ayak uydurmanın etkisinin diğer faktörlere kıyasla daha az olduğunu düşünmektedir (Tablo 5). Bu durum esnafların geleneksel yöntemlere bağl1lıklarıyla açıklanabilir. Bu çalışmada faktör analizi sonucunda elde edilen yenilikçilik boyutunun yanında geleneksel zanaat bilgisi boyutu esnafların bir özelliği olarak ortaya çıkmıştır. Yani araştırmada katılımcıların girişimciliğin gerekliliği olan yenilikçilik unsurunu göz ardı etmemekle beraber geleneksellikten de uzaklaşmadığı görülmektedir. Bu da esnafların girişimcilik sürecinde yenilikçi faaliyetlere ulaşmasında bir engel teşkil edebilir. 
Çalışmada başarı ihtiyacı, risk alma eğilimi, belirsizliğe tolerans, yenilik ve geleneksel zanaat bilgisi esnafların özelliği olarak ortaya çıkmıştır (Tablo 2). Denizli esnafının girişimcilik özelliklerini belirlemek üzere her bir özelliğin ortalaması alınmıştır. Bu çerçevede esnafların başarı ihtiyacı yüksek, risk alma eğilimleri orta, belirsizliğe tolerans düzeyleri düşük, geleneksel zanaat bilgisi orta ve yenilik düzeyleri yüksek seviyededir. Risk alma unsuru girişimcilerin en belirgin özelliği olmakla beraber, araştırmaya katılan esnaflar risk alma eğilimlerini orta seviye olarak algılamaktadırlar. Katılımcıların risk alma konusundaki çekinceleri araştırmanın diğer sorularına verilen cevaplarda da görülebilmektedir. Araştırmada örneklemin \%65,2' si 18-40 yaş arasındaki esnaflardan ve $\% 14,4^{\prime}$ ü 50 yaş ve üstü esnaflardan oluşmaktadır (Tablo 3). Tablo incelendiğinde esnafların yaşı arttıkça risk alma eğilimlerinin düştüğü görülmektedir. Bu durum genç yatırımcıların riskli yatırımlar nedeniyle karşılaştı̆̆ zararları telafi etmek için daha uzun zamana sahip olmaları ve böylece risk alma eğilimlerinin artmasından kaynaklanmaktadır (Anbar ve Eker, 2009: 136). Finansal risk toleransı ile demografik ve sosyo-ekonomik özellikler arasındaki ilişkiler değerlendirildiğinde yatırımcının yaşı arttıkça finansal risk toleransının azaldığı görülmektedir. Yani genç yatırımcıların risk toleransı yaşlı yatırımcılara göre daha yüksektir (Gündoğdu ve Çelik, 2018).

Araştırmada esnafların belirsizliğe tolerans düzeyleri düşük düzeyde bulunmuştur. Söz konusu bulgular esnaflarla yapılan diğer çalışma sonuçlarıyla (Kâhya ve İmamoğlu, 2013) örtüşmektedir. Bununla beraber elde edilen sonuçlar içinde bulunulan dönemin olumsuz etkilerinden biri olarak yorumlanabilir. Covid-19 salgınıla beraber ekonomik krizin yaşandığı bu süreçte bireylerin belirsizliklere toleransı daha da azalmıştır. Çünkü pandemi süreci bireylerin yaşamında pek çok belirsizlik ortaya çıkarmış ve kaygıyla birlikte yaşanılan durum tehdit edici olarak algılanmıştır (Kasapoğlu, 2020: 608). Araştırmada katılımcıların geleneksel zanaat bilgilerinin yanında yenilikçi faaliyetlerde de bulundukları sonucuna ulaşılmıştır. Söz konusu bulgular araştırmaya katılan esnafların, esnaf girişimciliğinin yanında az da olsa fırsatçı girişimcilik özelliklerini de taşıdıklarını göstermektedir. Küreselleşme ile birlikte bütün sektörlerde kendini gösteren değişimler birçok alanda yenilikler yaşanmasını kaçınılmaz kılmış (Mert ve Alan, 2020: 1060), esnaflar da faaliyetlerini bu yönde gerçekleştirmeye başlamışlardır.

Araştırmada katılımcıların sosyo-demografik özelliklerinin yapılan faktör analizi sonucunda beş boyuta ayrılan (başarı ihtiyacı, risk alma, belirsizliğe tolerans, yenilik ve geleneksel zanaat bilgisi) girişimcilik özellikleriyle ilişkisini test etmek üzere 10 tane hipotez oluşturulmuştur. Yapılan çalışmada risk alma ve yenilik boyutlarının katılımcıların yaşlarına göre farklılık gösterdiği sonucuna ulaşılmıştır. Tablo 7'e göre esnafların yaşı arttıkça risk alma eğilimleri düşmektedir. Yenilik boyutunun katılımcıların yaşlarına göre ilişkisi incelendiğinde yenilik boyutundaki en düşük oran 50 yaş üstünde görülmektedir (Tablo 7). $\mathrm{Bu}$ sonuçlara göre $\mathrm{H}_{1}$ kısmen desteklenmiştir. Girişimcilik alt boyutlarının katılımcıların eğitim düzeylerine göre ilişkisi incelendiğinde risk alma, belirsizliğe tolerans ve geleneksel zanaat bilgisi boyutları katılımcıların eğitim düzeyine göre farklılık göstermektedir (Tablo 8). Bu sonuçlara göre en az risk alan grubun ilköğretim mezunları en fazla risk alan grubun ise ön lisans mezunları olduğu görülmüştür. Belirsizliğe toleransı en yüksek olan grubun lisans ve lisansüstü eğitimi alanlar olduğu sonucuna ulaşılmıştır. Yani eğitim düzeyi arttıkça belirsizliğe toleransın arttığı görülmektedir. Başka bir ifadeyle, esnafların eğitim düzeyleri 
arttıkça bilgi düzeylerinin artıyor olması, belirsizliği göğüsleme ve belirsizlikle ilgili çözümlemeler konusunda cesaretlerini de artırmaktadır. Bununla birlikte geleneksel zanaat bilgisinin en yüksek olduğu grup yine lisans ve lisansüstü eğitimi alanlardır. Bu sonuçlara göre $\mathrm{H}_{2}$ kısmen desteklenmiştir. Çalışmada risk alma, belirsizliğe tolerans ve yenilik boyutlarının sektörlere göre anlamlı farklılık gösterdiği sonucuna ulaşılmıştır. Tablo 9'a göre risk alma ve yenilik boyutlarında en yüksek ortalamaya sahip grup otomotiv sektörü, en düşük ortalamaya sahip grup ise gida sektörüdür. Öte yandan belirsizliğe tolerans boyutunda en yüksek ortalamaya sahip grup gıda sektörü en düşük ortalamaya sahip grup ise otomotiv sektörüdür. Bu sonuçlara göre $\mathrm{H}_{3}$ kısmen desteklenmiştir. Araştırmada yenilik boyutunda işletmelerin kuruluş yıllarına göre anlamlı farklılık bulunmuştur. Tablo 10 incelendiğinde yakın geçmişte kurulan işletmelerin daha fazla yenilikçi değerler benimsediği görülmektedir. Buna göre $\mathrm{H}_{4}$ kısmen desteklenmiştir. Analiz sonuçlarına göre işletmenin hâlihazırdaki mülkiyeti ve girişimcilik alt boyutları arasındaki ilişki incelendiğinde belirsizliğe tolerans boyutunda anlamlı farklılık bulunmuştur (Tablo 11). Aileden olmayan kişi ya da kişilerle ortak olan esnafların, işletmelerinin mülkiyetine tek başına sahip olan veya aile ortaklığı bulunan esnaflara kıyasla belirsizliğe toleranslarının daha düşük olduğu sonucuna ulaşılmıştır. Bu sonuçlara göre $\mathrm{H}_{5}$ kısmen desteklenmiştir. Tablo 12'ye göre belirsizliğe tolerans ve geleneksel zanaat bilgisi boyutları işletmelerin mamullerinin tedarik şekline göre farklılık göstermektedir. Elde edilen sonuçlara göre satışını yaptığı mamulün üretimini kendi yapan işletmeye sahip olan esnafların tedariklerini başka işletmelerden yapan esnaflara göre geleneksel zanaat bilgisi ve belirsizliğe tolerans oranlarının yüksek olduğu görülmektedir. Bu bağlamda $\mathrm{H}_{6}$ kısmen desteklenmiştir. Risk alma, belirsizliğe tolerans ve yenilik boyutları katılımcıların işletmelerinin kendi mülkiyetlerinde olduğu dönemde, işletmelerde büyüme olup olmadığına göre farklılık göstermektedir (Tablo 13). Elde edilen sonuçlara göre işletmelerinde büyüme gösteren esnafların, diğer esnaflara kıyasla risk alma, yenilik ve belirsizliğe tolerans düzeyleri yüksektir. Tablo 14 incelendiğinde risk alma ve yenilik boyutları, katılımcıların işletmelerini gelecekte büyütme niyetine göre farklılaşmaktadır. İşletmelerini gelecekte büyüteceğine inanan esnafların, diğer esnaflara kıyasla risk alma ve yenilik düzeyleri yüksek bulunmuştur. Bu bağlamda $\mathrm{H}_{7}$ ve $\mathrm{H}_{8}$ kısmen desteklenmiştir. Analiz sonuçlarına göre belirsizliğe tolerans boyutu işletmelerde çalışan sayısına göre anlamlı farklılık göstermektedir. Tablo 15'e göre çalışan sayısı arttıkça belirsizliğe toleransın yükseldiği görülmektedir. Bu bağlamda $\mathrm{H}_{9}$ kısmen desteklenmiştir. Yapılan çalışmada risk alma, belirsizliğe tolerans ve geleneksel zanaat bilgisi boyutları pandemi döneminde küçülmeye giden işletmelere göre farklılık göstermektedir. Tablo 16 incelendiğinde işletmelerinde küçülmeye gitmeyen esnafların geleneksel zanaat bilgisinin yüksek olduğu görülmektedir. Küçülmeye giden esnafların risk alma düzeylerinin yüksek ancak belirsizliğe tolerans düzeylerinin düşük olduğu sonucuna ulaşılmıştır. Elde edilen sonuçlara göre $\mathrm{H}_{10}$ kısmen desteklenmiştir.

Esnaflar ekonomilerde istihdam yaratma, nitelikli iş gücü yetiştirme ve bu özellikleriyle bölgesel kalkınmada etkin rol oynamaktadır. Müşterilerle olan birebir ilişkilerinden dolayı, müşterilerin istek ve ihtiyaçları konusunda üretim firmalarını yönlendirmektedir (Çoban ve İrmiş, 2015: 37). Ayrıca işletmelerin tedarik süreçlerine aracılık etmektedir. Buna rağmen esnaf işletmelerinin sürdürülebilirlikleri küreselleşme süreci ve büyük işletmelerin rekabetçi baskısıyla tehlikeye girmiştir. Esnafların yaşadıkları sorunlar ve çözüm önerilerinin konu 
olduğu birçok çalışma yapılmış (Demirer vd., 2017; Çam ve Kabadayı, 2017) ancak girişimcilik literatüründe esnafların payı yeterince önemsenmemiş, esnaf faaliyetleri bu konuda geri planda tutulmuştur.

Sınırlı sermayeyle ticaret yapan ve geleneksel faaliyetlerle ekonomide yer alan esnaflar için girişimci özelliklerinin geliştirilmesinde; finansman desteğinin sağlanması ve yenilikçi faaliyetlere uyum sağlamalarının amaçlanması önemli bir yer tutmaktadır. Bu anlamda yeni girişimlerin kurulma ve büyüme aşamalarında esnaf işletmelerine destek sağlanmalıdır. Risk alma noktasında çekingen davranan ve daha çok geleneksel ya da teknik bilgiyle faaliyetlerine devam eden esnaflar, esnaf girişimciliği özelliği göstermektedir. Bu özellikleriyle girişimsel faaliyetlerde kısıtlı imkânları olan esnafların yenilikçilik kapasitelerinin geliştirilmesi, onların esnaf girişimciliği vasfından fırsatçı girişimciliği vasfına geçişinde yani girişimcilik özelliklerinin geliştirilmesinde köprü olarak görülmektedir. Devlet eliyle esnafın yenilikçi ürün geliştirme kapasitesinin artırılması ve yenilik kabiliyetlerinin güçlendirilmesine katkıda bulunulmalıdır. Ayrıca eğitimde bilinç düzeyinin yükseltilmesi, sanayi, üniversite, meslek liseleri ve meslek yüksekokulları ile iş birliklerinin artırılması; bu yolla esnafların yeni ürün ve projeler geliştirmesi sağlanmalıdır.

Covid-19 pandemi dönemi sosyal, ekonomik ve toplumsal sorunların küresel alana yayılmasına sebep olmuştur. Bu süreç esnafları ekonomik alanda büyük kayıplara uğratmıştır. Sokağa çıkma yasağı, sosyal mesafe zorunluluğu, kapalı ortamların yüksek risk düzeyinden dolayı yapılan uygulamalar ve bunların sonucu olarak alışveriş kültüründe yaşanan değişim en çok esnafların gelir düzeyini etkilemiştir. Nitekim bu dönemde faaliyet gösteren esnaflar işyerlerinin kapalı olmasından dolayı ekonomik olarak zor durumda kalmışlardır. İnternet kullanımının yaygınlaşmasıyla artış eğiliminde olan e-ticaretin salgından sonra daha da artması yerel esnaftan yapılan alışverişin azalmasına neden olmuştur. Bu açıdan esnaflara devlet tarafından e-ticarete yönelmelerini sağlayacak ilave finansal destek verilmelidir. Aynı zamanda esnaflara e-ticaret konusunda yeni yöntem ve teknikleri işletme fonksiyonları bağlamında öğreten ve geliştiren eğitim programlarının da devlet öncülüğünde yapılması önemlidir. Uygulanacak devlet politikalarının söz konusu alana doğru kaydırılması esnafların bu sürecin etkisinden en az hasarla çıkmasına yardımcı olacaktır. Ayrıca esnafların e-ticaretin imkânlarından faydalanmasına katkı sağlamak, ürünlerin pazarlama ve satışına destek olmak esnaf işletmelerinin dünyaya açılmasını, ürünlerini dünyaya tanıtmasını ve onların yerel işletme olmaktan öteye geçmesini sağlayacaktır.

Sonuç olarak, esnafların günümüz dünyasında hızla değişen ekonomik ve sosyal şartlara uyum sağlayacak şekilde rekabet güçleri ve kapasiteleri artırılmalıdır. Bunun için öncelikle esnaflar girişimsel faaliyetlerde bulunmaları için teşvik edilmelidir. Bu bağlamda esnaflara girişimcilik, ihracat süreçleri ve yenilikçilik hakkında eğitim, danışmanlık ve bilgi desteği sağlanmalıdır. 


\section{KAYNAKÇA}

Agbenyegah, A.T. (2013). "Challenges Facing Rural Entrepreneurship in Selected Areas in South Africa", North-West University, Potchefstroom.

Aguinis H,. Ansari Mahfooz A., Jayasingam S., \& Aafaqi R. (2008). “Perceived Entrepreneurial Success and Social Power", Management Research, 6(2), 121-137.

Akçakaya, N. ve Bağrıyanık, F. M. (2019). “Esnaflara Dair Çalışmaların Kayıp Halkası: Sosyal Sermaye", Selçuk Üniversitesi Edebiyat Fakültesi Dergisi, (41), 313-342.

Aksel, İ. ve Bağcı, Z. (2016). “Girişimcilik Eğilimi; Bir Kamu Üniversitesinin İ̈BF”sinde Öğrenim Gören Son Sınıf Öğrencilerinde Bir Araştırma”, İnsan ve Toplum Bilimleri Araştırmaları Dergisi, 5 (7), 2120-2133.

Alvora, C., Ribeiro, D. \& Salvador, R. (2007). Entrepreneurship: Concepts, Theory and Perspective, https://doi.org/10.1007/978-3-540-48543-8_1 , Springer.

Anbar, A. ve Eker, M. (2009). “Bireysel Yatırımcıların Finansal Risk Algılamalarını Etkileyen Demografik ve Sosyo-ekonomik Faktörler", ZKÜ Sosyal Bilimler Dergisi, 5 (9), 129-150.

Apospori, E., Papalexandris, N., \& Galanaki, E.(2005). “Entrepreneurial and Professional Ceos: Differences in Motive and Responsibility Profile", Leadership \& Organization Development Journal, 26 (2), 141-164.

Aytaç, S. E., Çarkoğlu, A., ve Ertan, G. (2017). “Türkiye'de Kişilerarası Sosyal Güven ve Bireysel Belirleyicileri”, ODTÜ Gelişme Dergisi, (44), 1-25.

Ballı, A. (2017). “Girişimcilik ve Girişimci Tipolojileri”, Süleyman Demirel Üniversitesi Sosyal Bilimler Enstitüsü Dergisi, (29), 143-166

Bayrak, S. K. ve Mert, E. (2016). “Girişimcilikte Sosyal Değer İnşası: Sosyal Girişimcilik”, International Conference On Eurasian Economies, 161-169.

Campo, J. L. M. (2010). “The Propensity For Entrepreneurship: Psychological and Social Factors" ,Cuadernos Latin oamericanos de Administración, 6 (10),51-76.

Cho, J. \& Lee, J. (2006). “An İntegrated Model of Risk and Risk-Reducing Strategies”, Journal of Business Research, 59,112-120.

Çam, A. V. ve Kabadayı, T. (2017). “Esnafların Karşılaştıkları Sorunlar Ve Çözüm Önerileri: Gümüşhane İlinde Bir Uygulama”, Global Journal of Economics and Business Studies, 6 (11), 98-108.

Çoban, H. ve İrmiş, A. (2015). “Girişimcilik Kültürü Açısından Geleneksel Alış-Veriş Yerlerindeki Esnaf ile Modern Avm'lerdeki Esnafın Karşılaştırılması”, Pamukkale İşletme ve Bilişim Yönetimi Dergisi, 2 (1), 29-38.

Dees, G. J. (2001). "The meaning of Social Entreprenurship" The Fuqua School of Business, Duke University, 1-5.

Demirer, Ö., Bayramoğlu, G., Şeker, Y., Konak, F., ve Şahin, M. (2017). "Esnaf Ve Sanatkâr İşletmelerinin Sorunları Ve Çözüm Önerileri: Çorum İlinde Bir Araştırma”, Ömer Halisdemir Üniversitesi İktisadi ve İdari Bilimler Fakültesi Dergisi, 10 (1), 153-170. 
Dinis, A., Paço, A., Ferreira, J., Raposo, M. \& Rodriugues G.R. (2013) "Psychological Characteristics and Entrepreneurial Intentions Among Secondary Students", Education + Training, 55(8-9), 763-782.

Durukan, T. (2007). “Dünden Bugüne Girişimcilik ve 21. Yüzyılda Girişimciliğin Önemi”, Girişimcilik ve Kalkınma Dergisi, 1(2), 25-37

Eroğlu, F., Çoban, H., ve Koç, M. (2015). “Toplumsal Kalkınma ve Kadın Girişimciliği Üzerine Bir Araştırma", International Conference On Eurasıan Economies, 534-543.

Filley, A. C. \& Aldag, R. J. (1978). “Characteristics and Measurement of an Organizational Typology" Academy of Management Journal, 21 (4), 578-591.

Güler B. Y., Bozacı, İ. ve Karakaya, E. (2016). “Kültür ile Girişimcilik Eğilimi Ve Ortaklık Kültürü İlişkilerinin İncelenmesi: Kırıkkale İli Üniversite Öğrencileri Örneği”, AKÜ İ̈BF Dergisi, 18 (2), 23-33.

Gündoğdu, A. ve Çelik, Ş. (2018). “Türk Sermaye Piyasasında Kuşaklar Arasında Yatırımcı ve Portföy Farklılıkları"', Istanbul Business Research, 47 (1), 46-63.

Güven, H. (2020). “Covid 19 Pandemik Krizi Sürecinde E-Ticarette Meydana Gelen Değişimler" , Avrasya Sosyal ve Ekonomi Araştırmaları Dergisi, 7(5), 251-268.

Halis, M., Şenkal, A. ve Türkay, O. (2009). “Kültür, Ortaklık ve Rekabet: Türkiye'ye İlişkin Rakamlar", Journal Of Azerbaijani Studies, 444-460.

Heckert, T. M., Cuneio G., Hannah, A. P., Adams, P. J., Droste, H. E., Mueller, M. A., Wallis, H. A., Griffin, C. M. \& Roberts, L. L. (1999). “Creation of a New Needs Assessment Questionnaire", Journal of Social Behavior and Personality, 15 (1), 121-136.

Işık, N., Göktaş, D., Kılınç, E. (2011). “İktisadi Büyümede Girişimciliğin Rolü”, Girişimcilik ve Kalkınma Dergisi, 6 (1), 186-210.

İrmiş, A. ve Barutçu, E. (2012). “Öğrencilerin Kendilerini Girişimci Bir Kişiliğe Sahip Görmelerini ve İş Kurma Niyetlerini Etkileyen Faktörler: Bir Alan Araştırması", Atatürk Üniversitesi İktisadi ve İdari Bilimler Dergisi, 26 (2), 1-25.

İrmiş, A. ve Özdemir, L. (2011). “Girişimcilik ve Yenilik İlişkisi”, Yönetim Bilimleri Dergisi, 9 (1), 137-161.

Kâhya, C. ve İmamoğlu, İ. Kays (2013). “Sosyo-Demografik Özellikler ve Girişimcilik İlişkisinin Yerel Kalkınma Bağlamında Değerlendirilmesi (Bayburt İli Örneği)", Akademik Bakış Dergisi, (38), 1-14.

Karol, S. (2013). "Schumpeter's View on Innovation An Entrenepeurship", SSRN: Electronic Journal, 89-95.

Kasapoğlu, T. M. (2020). “Covid-19 Pandemisinde İlan Edilen Sokağa Çıkma Yasaklarının İdare Hukuku Yönüyle Değerlendirilmesi”, İnönü Üniversitesi Hukuk Fakültesi Dergisi, $11(2), 550-566$.

Kırılmaz, S. (2012). "Sosyal Girişimciliğin Başarı Faktörlerinin Girişimci Kişilik ve Dönüştürücü Liderlik Bağlamında Araştırılması", Doktora Tezi, Çanakkale Onsekiz Mart Üniversitesi, Sosyal Bilimler Enstitüsü. 
Koh, H.C., (1996). “Testing Hypotheses of Entrepreneurial Characteristic: A Study of Hong Kong", Journal of Managerial Psychology, 11 (3), 12-25.

Kuvan, H. (2007). “Türk Girişimcilerinin Yaşam Ve Çalışma Değerleri Malatyalı Girişimciler Üzerine Bir Araştırma", Doktora Tezi, Süleyman Demirel Üniversitesi Sosyal Bilimler Enstitüsü, Isparta.

Mert, G. ve Alan, T. (2020). "Girişimcilerin Kriz Algısı ve Kriz ile Başa Çıkma Stratejileri”, International Social Mentality and Researcher Thinkers Journal, 6 (32), 1047-1064.

Mueller, S. L. \& Thomas, A. S. (2000). “Culture and Entrepreneruial Potential: A Nine Country Study of Locus Of Control and İnnovativeness", Journal of Business Venturing, 16 (1), 51-75.

Mujahid, S., Mubarik, S. \& Naghavi, N. (2019.) “Prioritizing Dimensions of Entrepreneurial Ecosystem: A Proposed Framework", Journal of Global Entrepreneurship Research, 9 (1), $1-21$.

Nasip, S., Amirul, S. R. , Jr Sondoh, S. L \& Tanakijinal, G. H. (2017). “Psychological Characteristics and Entrepreneurial İntention", Education + Training, 59 (7-8), 825-840.

Nişancı, Z. N. (2015). “Göçmen Girişimcilik Üzerine: Pittsburgh'taki Türk Girişimciler”, Girişimcilik ve Kalkınma Dergisi, 10 (1), 1-28.

Norton, R. W. (1975). "Measurement of Ambiguity Tolerance", Journal of Personality Assessment, 39(6),607-619.

Organisation for Economic Co-operation and Development (2020). "How is Life in 2020?" Measuring Well-being- Highlights, March 2020. https://doi.org/10.1787/9870c393-en , (13.04.2020).

Özdevecioğlu, M. ve Karaca, M. (2015). Girişimcilik, Girişimci Kişilik, Konya: Eğitim Yayınevi.

Robinson, P.B., Stimpson, D.V., Huefner, J.C., \& Hunt, H.K. (1991). “An Attitude Approach to the Prediction of Entreprenurship", Entreprenurship Theory \& Practice, Summer, 15(4), 13-30.

Rotter, J.B., (1954). Social Learning and Clinical Psychology, Englewood Cliifs: Prectice-Hall.

Salt, A. M. (2019). Gelenekten Moderniteye Sakarya'da Esnaf Kültürünün Değişimi, Yüksek Lisans Tezi, Sakarya Üniversitesi Sosyal Bilimler Enstitüsü. Sakarya.

Sargut, S. (2001). Kültürler Arası Farklılaşma ve Yönetim, İmge Kitapevi, 2.Basım, Ankara.

Smith, N. R. \& Miner, J. B. (1983). "Type of Entrepreneur, Type of Firm, and Managerial Motivation: Implications for Organizational Life Cycle Theory" Strategic Management Journal, 4 (4), 325-340.

Timuroğlu, M. K., ve Çakır, S. (2014). “Girişimcilerin Yeni Bir Girişim Yapma Niyetlerinin Risk Alma Eğilimi ile İlişkisi”, Afyon Kocatepe Üniversitesi İktisadi ve İdari Bilimler Fakültesi Dergisi, (16), 119-136. 
Uzun, E. ve Dirlik, S. (2007). “Kobi Sahiplerinin Girişimcilik, Kişilik Ve Liderlik Özelliklerinin Değerlendirilmesi: Muğla İlinde Ampirik Bir Araştırma", İstanbul Ticaret Üniversitesi Sosyal Bilimler Dergisi, 6 (11), 133-148. 